\title{
İstanbul Üniversitesi Edebiyat Fakültesi Bilim Tarihi Bölümü'nün 2016-2020 Yılları Faaliyet Raporu
}

\section{6-2020 Activity Report of the Department of the History of Science, Faculty of Letters, Istanbul University}

Gaye Şahinbaş Erginöz ${ }^{1}$ (D)

Doç. Dr. İstanbul Üniversitesi, Edebiyat Fakültesi, Bilim Tarihi Bölümü, İstanbul, Türkiye

\section{ORCID: G.Ş.E. 0000-0001-6951-477X}

Sorumlu yazar/Corresponding author: Gaye Şahinbaş Erginöz

İstanbul Üniversitesi, Edebiyat Fakültesi, Bilim Tarihi Bölümü, İstanbul, Türkiye

E-posta/E-mail: gayesah@istanbul.edu.tr

Başvuru/Submitted: 20.12 .2020 Revizyon Talebi/Revision Requested: 31.03.2021

Son Revizyon/Last Revision Received: 14.04.2021

Kabul/Accepted: 23.04 .2021

Online yayın / Published online: 05.07.2021

Atıf/Citation: Şahinbaş Erginöz, Gaye. “istanbul Üniversitesi Edebiyat Fakültesi Bilim Tarihi Bölümü'nün 2016-2020 Yılları Faaliyet Raporu." Osmanlı Bilimi Araştırmaları 22, 2 (2021): 395-445. https://doi.org/10.26650/oba.843688

\section{ÖZ}

Bu faaliyet raporunda İstanbul Üniversitesi Edebiyat Fakültesi Bilim Tarihi Bölümü'nün 2016-2020 yılları arasındaki eğitim-öğretim, araştırma ve yayın faaliyeti ele alınmıştır. Eğitim-öğretim kapsamında lisans ve lisansüstü ders programlarına yer verilmiş; Bölüm öğretim üyelerinin danışmanlığında hazırlanan lisansüstü tezler hakkında bilgi verilmiştir. Bilim Tarihi Bölümü tarafından düzenlenen sergi, sempozyum ve konferansların yanısıra bölüm öğrencilerinin düzenledikleri kongreler tanıtılmıştır. Ayrıca Bilim Tarihi Bölümü'nün yayını olan Osmanlı Bilimi Araştırmaları dergisinin 2016-2020 yılları arasında çıkan sayılarında yer alan makalelerin başııkarı listelenmiştir. Raporun sonunda ise, bölüm mensuplarının yayın listeleri ile yurt içi ve yurt dışı toplantılarda sundukları bildiriler ve diğer etkinlikleri yer almıştır.

Anahtar sözcükler: Bilim Tarihi Bölümü, İstanbul Üniversitesi, eğitim ve öğretim, bilimsel araştırma, Osmanlı Bilimi Araştırmaları

\section{ABSTRACT}

The purpose of this report is to publicize the educational and research activities of the Department of the History of Science, Faculty of Letters, Istanbul University between 2016 and 2020. The report includes the curricula of the Department's undergraduate and postgraduate programs and synopses of postgraduate theses completed in the Department. It also contains information on exhibitions, symposia, and conferences organized by the Department, as well as student congresses. In addition, a list of articles published during this period in the Department's journal, Studies in Ottoman Science / Osmanlı Bilimi Araştırmaları, is provided. The report ends with a list of publications by members of the Department and of papers they have presented at national and international meetings.

Keywords: Department of the History of Science, Istanbul University, education and teaching, scientific research, Studies in Ottoman Science 


\section{Giriş}

Bilim Tarihi Bölümü’nün 2016 yılı öncesi faaliyetlerine Osmanlı Bilimi Araştırmaları dergisinde (https://dergipark.org.tr/tr/pub/iuoba) düzenli aralıklarla yer verilmiştir. Bu yazıda ise, Bölüm'ün 2016-2020 yılları arasındaki eğitim-öğretim, araştırma ve yayın faaliyetleri tanitilacaktır.

Bilim Tarihi Bölümü, Yüksek Öğretim Kurulu’nun (YÖK) 23 Kasım 1984 tarihli kararı ile İstanbul Üniversitesi Edebiyat Fakültesi Felsefe Bölümü bünyesi içinde Anabilim Dalı olarak kurulmuş, 3 Nisan 1989 tarihli kararı ile de Bölüm'e dönüştürülmüştür. 1992-1999 yılları arasında dört yıllık Lisans Programını uygulamaya başlayan Bilim Tarihi Bölümü, 18 Nisan 2000 tarihli YÖK kararı ile Felsefe Bölümü içinde anabilim dalı olarak yer almıştır. 2000-2009 yılları arasında Felsefe Bölümü'nde faaliyet gösteren Bilim Tarihi Anabilim Dalı, Yüksek Öğretim Kurulu'nun 4 Kasım 2009 tarihli kararı ile yeniden Bölüm statüsüne kavuşmuştur. 2018-2019 eğitim-öğretim yılından itibaren, YÖK'ün 03.07.2017 tarih ve 53350 sayılı yazısı ile Bilim Tarihi Bölümü içinde Bilim Tarihi Anabilim Dalı açılmıştır. Bilim Tarihi Bölümü başkanı Prof. Dr. Feza Günergun, aynı zamanda Bilim Tarihi Anabilim Dalı başkanlığını da yürütmektedir. Böylece İ.Ü. Edebiyat Fakültesi içindeki Bilim Tarihi çalışmaları 2020 yılı itibariyle otuz altıncı yılına ulaşmış bulunmaktadır.

\section{Lisans Eğitimi}

Bilim Tarihi Bölümü’nde dört yıllık lisans eğitimini başarıyla tamamlayanlar "Bilim Tarihi Bölümü Mezunu” unvanını alırlar. Mezunların, bilim ve teknoloji mirasına sahip devlet veya özel kültür kurumlarında (kütüphane, müze, arşiv vb.), bilimin popülerleştirilmesi yönündeki çalışmalara katkıda bulunmak üzere çeşitli basın ve yayın organlarında çalışma imkânına sahip olmaları beklenir. Bilim Tarihi Bölümü’nün 2016-2020 yılları arasında açmış olduğu zorunlu ve seçmeli lisans dersleri aşağıdaki gibidir. ${ }^{1}$

\section{5-2017 Ders Yılında Uygulanan Lisans Ders Programı²}

\section{SINIF}

\section{Güz Dönemi}

Bilim Tarihine Giriş (3kr.)

Yrd. Doç. Dr. Meltem Kocaman

1 Lisans ve lisansüstü derslere ait tüm ders programları, Bilim Tarihi Bölümü’nün ders programı arşivinden elde edilmiştir.

2 1.Sınıf ders programında, Bilim Tarihi Bölümü 1.Sınıf öğrencilerinin almak zorunda oldukları bölüm derslerine yer verilmiştir. Bu derslerin yanısıra, her sene 1. sınıfların ders programı içinde hem güz hem de bahar dönemlerinde tüm Edebiyat Fakültesi ögrencilerinin almak zorunda oldukları ve Fakülte tarafindan verilen Atatürk İlkeleri ve İnkılâp Tarihi, Türk Dili, Yabancı Dil, Güzel Sanatlar ve Beden Eğitimi dersleri de yer almaktadır. 
Eskiçağda Bilim ve Teknik 1 (3kr.)

Avrupa'da Bilim ve Teknoloji Mirası (2kr.)

Matematik Tarihi 1 (3kr.)

\section{Bahar Dönemi}

Bilim ve Toplum (3kr.)

Eskiçağda Bilim ve Teknik 2 (3kr.)

Türkiye'de Bilim ve Teknoloji Mirası (2kr.)

Matematik Tarihi 2 (3kr.)
Yrd. Doç. Dr. Gaye Şahinbaş Erginöz

Prof. Dr. Feza Günergun

Prof. Dr. Sevtap Kadıoğlu

Yrd. Doç. Dr. Meltem Kocaman

Yrd. Doç. Dr. Gaye Şahinbaş Erginöz

Prof. Dr. Feza Günergun

Prof. Dr. Sevtap Kadıoğlu

\section{SINIF}

\section{Güz Dönemi}

\section{Zorunlu}

Ortaçağ İslam Dünyasında

Bilim ve Teknoloji (2kr.)

Fizik Tarihi 1 (2kr.)

Bilim Tarihi Kaynak Metinleri 1 (2kr.)

Bilim Tarihçileri İçin Tarih Yazımı (3kr.)

Mimarlık Mirası (3kr.)

Prof. Dr. Mustafa Kaçar

Yrd. Doç. Dr. Meltem Kocaman

Yrd. Doç. Dr. Yusuf Alperen Aydın

Doç. Dr. Tuncay Zorlu

Doç. Dr. Deniz Mazlum

\section{Seçmeli}

Amerikan Silah Teknolojisi ve

Osmanlı Devleti (2kr.)

Yrd. Doç. Dr. Metin Ünver

Madencilik Tarihi (2kr.)

Yrd. Doç. Dr. Selma Akay Ertürk

\section{Bahar Dönemi}

\section{Zorunlu}

Rönesans'ta Bilim (2kr.) 
Eczacılık Tarihi (2kr.)

Fizik Tarihi 2 (2kr.)

Bilim Tarihi Kaynak Metinleri 2 (2kr.)

Bilim ve Medya (2kr.)

Eskiçağda Bilim Semineri (4kr.)

\section{Seçmeli}

Bilim ve Sanat (3kr.)

Savaş ve Teknoloji (2kr.)

\section{SINIF}

\section{Güz Dönemi}

\section{Zorunlu}

Bilim Felsefesi (2kr.)

Osmanlı Türkiye'sinde Bilim 1 (2kr.)

Yerbilimleri Tarihi (2kr.)

Aydınlanma Çağında Bilim (2kr.)

Bilgisayarların Tarihi (2kr.)

Coğrafya Tarihi (2kr.)

\section{Bahar Dönemi}

\section{Zorunlu}

Bilim Kurumlarının Tarihsel Gelişimi (2kr.)

Osmanlı Türkiye'sinde Bilim 2 (2kr.)

Yakınçağda Avrupa'da Bilim (2kr.)

Sağlık Tarihi (2kr.)
Prof. Dr. Afife Mat

Yrd. Doç. Dr. Meltem Kocaman

Yrd. Doç. Dr. Yusuf Alperen Aydın

Doç. Dr. Belkıs Ulusoy

Yrd. Doç. Dr. Gaye Şahinbaş Erginöz

Prof. Dr. Şefik Görkey

Yrd. Doç. Dr. Gültekin Yıldız
Yrd. Doç. Dr. Özgüç Güven

Prof. Dr. Mustafa Kaçar

Doç. Dr. Ferhat Özçep

Yrd. Doç. Dr. Kaan Ata

Yrd. Doç. Dr. Kaan Ata

Yrd. Doç. Dr. Selma Akay Ertürk
Prof. Dr. Sevtap Kadıoğlu

Prof. Dr. Mustafa Kaçar

Yrd. Doç. Dr. Meltem Kocaman

Doç. Dr. Rainer Brömer 
Haritacılık Tarihi (2kr.)

Bizans’ta Bilim (2kr.)

\section{Seçmeli}

Yenilik İktisadı (2kr.)

Ortaçağ Avrupasında Tıp (2kr.)

\section{SINIF}

\section{Güz Dönemi}

\section{Zorunlu}

Sanayi Devrimi (2kr.)

Astronomi Tarihi 1 (2kr.)

Cumhuriyet Türkiyesi’nde Bilim (2kr.)

Biyoloji Tarihi (2kr.)

Osmanlı ve Bilim Semineri (4kr.)

\section{Seçmeli}

Teknoloji Tarihi 1 (2kr.)

Temel Bilimler ve Bilimsel

Düşüncenin Gelişimi (2kr)

\section{Bahar Dönemi}

\section{Zorunlu}

Astronomi Tarihi 2 (2kr.)

Kimya Tarihi (2kr.)

20.Yüzyılda Fizik Tarihi (2kr.)

Cumhuriyet ve Bilim Semineri (2kr.)

Soğuk Savaş ve Bilim (2kr.)

Bilim Etiği (2kr.)
Prof. Dr. Cengizhan İpbüker

Prof. Dr. Feza Günergun

Yrd. Doç. Dr. Kadir Yıldırım

Prof. Dr. Şefik Görkey
Prof. Dr. Emre Dölen

Prof. Dr. Feza Günergun

Prof. Dr. Sevtap Kadıoğlu

Doç. Dr. Rainer Brömer

Prof. Dr. Sevtap Kadıŏglu

Prof. Dr. Zeki Tez

Prof. Dr. Ahmet Özok
Prof. Dr. Feza Günergun

Prof. Dr. Emre Dölen

Yrd. Doç. Dr. Alper Dizdar

Prof. Dr. Feza Günergun

Yrd. Doç. Dr. Kaan Ata

Doç. Dr. Rainer Brömer 


\section{Seçmeli}

Teknoloji Tarihi 2 (2kr.)

Prof. Dr. Zeki Tez

Tarih Böyunca Göçler (2kr.)

Yrd. Doç. Dr. Selma Akay Ertürk

\section{6-2018 Ders Yılında Uygulanan Lisans Ders Programı}

\section{SINIF}

\section{Güz Dönemi}

Bilim Tarihine Giriș (3kr.)

Yrd. Doç. Dr. Meltem Kocaman

Eskiçağda Bilim ve Teknik 1 (3kr.)

Yrd. Doç. Dr. Gaye Şahinbaş Erginöz

Avrupa'da Bilim veTeknoloji Mirası (2kr.)

Prof. Dr. Feza Günergun

Matematik Tarihi 1 (3kr.)

Yrd. Doç. Dr. Özkan Değer

\section{Bahar Dönemi}

Bilim ve Toplum (3kr.)

Yrd. Doç. Dr. Meltem Kocaman

Eskiçağda Bilim ve Teknik 2 (3kr.)

Yrd. Doç. Dr. Gaye Şahinbaş Erginöz

Türkiye'de Bilim ve Teknoloji Mirası (2kr.)

Matematik Tarihi 2 (3kr.)

Prof. Dr. Feza Günergun

Yrd. Doç. Dr. Özkan Değer

\section{SINIF}

\section{Güz Dönemi}

\section{Zorunlu}

Ortaçağ İslam Dünyasında Bilim ve

Teknoloji (2kr.)

Prof. Dr. Mustafa Kaçar

Fizik Tarihi 1 (2kr.)

Yrd. Doç. Dr. Meltem Kocaman

Bilim Tarihi Kaynak Metinleri 1 (2kr.)

Yrd. Doç. Dr. Yusuf Alperen Aydın

Bilim Tarihçileri İçin Tarih Yazımı (2kr.)

Doç. Dr. Tuncay Zorlu 
Mimarlık Mirası (2kr.)

\section{Seçmeli}

Amerikan Silah Teknolojisi ve

Osmanlı Devleti (2kr.)

Eleştirel Düşünme (2kr.)

\section{Bahar Dönemi}

\section{Zorunlu}

Rönesans’ta Bilim (2kr.)

Fizik Tarihi 2 (2kr.)

Bilim Tarihi Kaynak Metinleri 2 (2kr.)

Bilim ve Medya (2kr.)

Eczacılık Tarihi (2kr.)

Eskiçağda Bilim Semineri (4kr.)

\section{Seçmeli}

Bilim ve Sanat (3kr.)

Savaş ve Teknoloji (2kr.)

\section{SINIF}

\section{Güz Dönemi}

\section{Zorunlu}

Bilim Felsefesi (2kr.)

Osmanlı Türkiye'sinde Bilim 1 (2kr.)

Yerbilimleri Tarihi (2kr.)

Aydınlanma Çağında Bilim (2kr.)

Bilgisayarların Tarihi (2kr.)
Doç. Dr. Deniz Mazlum

Yrd. Doç. Dr. Metin Ünver

Yrd. Doç. Dr. Murad Omay
Prof. Dr. Sevtap Kadıŏglu

Yrd. Doç. Dr. Meltem Kocaman

Yrd. Doç. Dr. Yusuf Alperen Aydın

Prof. Dr. Belkıs Ulusoy

Yrd. Doç. Dr. Gaye Şahinbaş Erginöz

Yrd. Doç. Dr. Gaye Şahinbaş Erginöz

Prof. Dr. Şefik Görkey

Yrd. Doç. Dr. Özgür Kolçak
Yrd. Doç. Dr. Özgüç Güven

Prof. Dr. Mustafa Kaçar

Doç. Dr. Ferhat Özçep

Yrd. Doç. Dr. Kaan Ata

Yrd. Doç. Dr. Kaan Ata 
Coğrafya Tarihi (2kr.)

Yrd. Doç. Dr. Selma Akay Ertürk

\section{Bahar Dönemi}

\section{Zorunlu}

Bilim Kurumlarının Tarihsel Gelişimi (2kr.) Prof. Dr. Sevtap Kadığlu

Osmanlı Türkiye'sinde Bilim 2 (2kr.)

Prof. Dr. Mustafa Kaçar

Yakınçağda Avrupa'da Bilim (2kr.)

Yrd. Doç. Dr. Meltem Kocaman

Sağlık Tarihi (2kr.)

Doç. Dr. Rainer Brömer

Haritacılık Tarihi (2kr.)

Prof. Dr. Cengizhan İpbüker

Bizans’ta Bilim (2kr.)

Prof. Dr. Feza Günergun

\section{Seçmeli}

Yenilik İktisadı (2kr.)

Yrd. Doç. Dr. Kadir Yıldırım

Ortaçağ Avrupasında Tıp (2kr.)

Prof. Dr. Şefik Görkey

\section{SINIF}

Güz Dönemi

\section{Zorunlu}

Sanayi Devrimi (2kr.)

Prof. Dr. Emre Dölen

Astronomi Tarihi 1 (2kr.)

Yrd. Doç. Dr. Meltem Kocaman

Cumhuriyet Türkiyesi'nde Bilim (2kr.)

Prof. Dr. Sevtap Kadıoğlu

Biyoloji Tarihi (2kr.)

Doç. Dr. Rainer Brömer

Osmanlı ve Bilim Semineri (4kr.)

Prof. Dr. Sevtap Kadıoğlu

\section{Seçmeli}

Teknoloji Tarihi 1 (2kr.)

Prof. Dr. Aytekin Çökelez

Temel Bilimler ve Bilimsel

Düşüncenin Gelişimi (2kr)

Prof. Dr. Ahmet Özok 


\section{Bahar Dönemi}

\section{Zorunlu}

Astronomi Tarihi 2 (2kr.)

Yrd. Doç. Dr. Meltem Kocaman

Kimya Tarihi (2kr.)

Prof. Dr. Emre Dölen

20.Yüzyılda Fizik Tarihi (2kr.)

Yrd. Doç. Dr. Alper Dizdar

Cumhuriyet ve Bilim Semineri (2kr.)

Prof. Dr. Feza Günergun

Soğuk Savaş ve Bilim (2kr.)

Yrd. Doç. Dr. Kaan Ata

Bilim Etiği (2kr.)

Doç. Dr. Rainer Brömer

Seçmeli

Teknoloji Tarihi 2 (2kr.)

Prof. Dr. Aytekin Çökelez

\section{7-2019 Ders Yılında Uygulanan Lisans Ders Programı}

1.SINIF

Güz Dönemi

Bilim Tarihine Giriş (3kr.)

Dr. Öğr. Üyesi Meltem Kocaman

Eskiçağda Bilim ve Teknik 1 (3kr.)

Dr. Öğr. Üyesi Gaye Şahinbaş Erginöz

Avrupa'da Bilim veTeknoloji Mirası (2kr.)

Prof. Dr. Feza Günergun

Matematik Tarihi 1 (3kr.)

Dr. Öğr. Üyesi Özkan Değer

\section{Bahar Dönemi}

Bilim ve Toplum (3kr.)

Dr. Öğr. Üyesi Meltem Kocaman

Eskiçağda Bilim ve Teknik 2 (3kr.)

Dr. Öğr. Üyesi Gaye Şahinbaş Erginöz

Türkiye'de Bilim ve Teknoloji Mirası (2kr.)

Prof. Dr. Feza Günergun

Matematik Tarihi 2 (3kr.)

Dr. Öğr. Üyesi Özkan Değer 


\section{SINIF}

\section{Güz Dönemi}

\section{Zorunlu}

Ortaçağ İslam Dünyasında Bilim ve

Teknoloji (2kr.)

Prof. Dr. Sevtap Kadıoğlu

Fizik Tarihi 1 (2kr.)

Dr. Öğr. Üyesi Meltem Kocaman

Bilim Tarihi Kaynak Metinleri 1 (2kr.)

Dr. Öğr. Üyesi Mehmet Sait Türkhan

Bilim Tarihçileri İçin Tarih Yazımı (2kr.)

Dr. Öğr. Üyesi Gaye Danışan

Mimarlık Mirası (2kr.)

Doç. Dr. Deniz Mazlum

\section{Seçmeli}

Amerikan Silah Teknolojisi ve

Osmanlı Devleti (2kr.)

Dr. Öğr. Üyesi Metin Ünver

Eleştirel Düşünme (2kr.)

Dr. Öğr. Üyesi Murad Omay

Madencilik Tarihi (2kr.)

Dr. Öğr. Üyesi Selma Akay Ertürk

Felsefi ve Eleştirel Düşünce (2kr.)

Prof. Dr. Cengiz Çakmak

Kültürel Etkinlikler $1(2 \mathrm{kr} \text {. })^{3}$

\section{Bahar Dönemi}

\section{Zorunlu}

Rönesans’ta Bilim (2kr.)

Fizik Tarihi 2 (2kr.)

Bilim Tarihi Kaynak Metinleri 2 (2kr.)

Bilim ve Medya (2kr.)
Dr. Öğr. Üyesi Gaye Danışan

Dr. Öğr. Üyesi Meltem Kocaman

Dr. Öğr. Üyesi Mehmet Sait Türkhan

Prof. Dr. Belkıs Ulusoy

3 İlk defa 2018-2019 eğitim-öğretim yılından itibaren Edebiyat Fakültesi’nin tüm bölümlerinde ikinci ve üçüncü sınıf öğrencileri için güz ve bahar dönemlerinde Kültürel Ekinlikler adı altında seçmeli bir ders açılmıştır. Her sınıfın kendi danışmanı tarafından verilen bu ders kapsamında öğrencinin sosyal faaliyetlerini geliştirmesi hedeflenmiştir. Bu doğrultuda ö̆rrencilerin katıldıkları bilim ve sanat etkinlikleri ve gerçekleştirdikleri sosyal sorumluluk projelerini içeren bir değerlendirme raporu hazırlamaları gerekmektedir. Dersin değerlendirmesi, öğrencinin teslim edeceği "Kültürel Etkinlikler Dersi Değerlendirme Raporu” çerçevesinde yapılmıștır. 
Eczacılık Tarihi (2kr.)

Eskiçağda Bilim Semineri (2kr.)

\section{Seçmeli}

Bilim ve Sanat (3kr.)

Akıl Yürütme ve Temellendirme (2kr.)

Kültürel Etkinlikler 2 (2kr.)

\section{SINIF}

\section{Güz Dönemi}

\section{Zorunlu}

Bilim Felsefesi (2kr.)

Osmanlı Türkiye'sinde Bilim 1 (2kr.)

Yerbilimleri Tarihi (2kr.)

Aydınlanma Çă̆ında Bilim (2kr.)

Bilgisayarların Tarihi (2kr.)

\section{Seçmeli}

Coğrafya Tarihi (2kr.)

Kültür Bilimleri Felsefesi (2kr.)

Kültürel Etkinlikler 3 (2kr.)

\section{Bahar Dönemi}

\section{Zorunlu}

Bilim Kurumlarının Tarihsel Gelişimi (2kr.)

Osmanlı Türkiye'sinde Bilim 2 (2kr.)

Yakınçağda Avrupa'da Bilim (2kr.)
Dr. Öğr. Üyesi Gaye Şahinbaş Erginöz

Dr. Öğr. Üyesi Gaye Şahinbaş Erginöz

Prof. Dr. Şefik Görkey

Dr. Öğr. Üyesi Murad Omay
Dr. Öğr. Üyesi Vedat Kamer

Prof. Dr. Feza Günergun

Prof. Dr. Ferhat Özçep

Dr. Öğr. Üyesi Kaan Ata

Dr. Öğr. Üyesi Kaan Ata

Prof. Dr. Ayhan Bıçak

Prof. Dr. Sevtap Kadıŏlu

Dr. Öğr. Üyesi Meltem Kocaman

Dr. Öğr. Üyesi Meltem Kocaman 
Sağlık Tarihi (2kr.)

Haritacılık Tarihi (2kr.)

\section{Seçmeli}

Bizans’ta Bilim (2kr.)

Ortaçağ Avrupasında Tıp (2kr.)

Medeniyet Tarihi $(2 \mathrm{kr} .)^{4}$

Kültürel Etkinlikler 4 (2kr.)
Doç. Dr. Rainer Brömer

Prof. Dr. Cengizhan İpbüker

Prof. Dr. Feza Günergun

Prof. Dr. Şefik Görkey

\section{SINIF}

\section{Güz Dönemi}

\section{Zorunlu}

Sanayi Devrimi (2kr.)

Prof. Dr. Emre Dölen

Astronomi Tarihi 1 (2kr.)

Prof. Dr. Feza Günergun

Cumhuriyet Türkiyesi'nde Bilim (2kr.)

Prof. Dr. Sevtap Kadıoğlu

Biyoloji Tarihi (2kr.)

Doç. Dr. Rainer Brömer

Osmanlı ve Bilim Semineri (2kr.)

Prof. Dr. Sevtap Kadıoğlu

\section{Seçmeli}

Teknoloji Tarihi 1 (2kr.)

Prof. Dr. Aytekin Çökelez

Temel Bilimler ve Bilimsel

Düşüncenin Gelişimi (2kr)

Prof. Dr. Ahmet F. Özok

Etik ve Estetik (2kr.) 


\section{Bahar Dönemi}

\section{Zorunlu}

Astronomi Tarihi 2 (2kr.)

Prof. Dr. Feza Günergun

Kimya Tarihi (2kr.)

Prof. Dr. Emre Dölen

20.Yüzyılda Fizik Tarihi (2kr.)

Dr. Öğr. Üyesi Kaan Ata

Cumhuriyet ve Bilim Semineri (2kr.)

Prof. Dr. Feza Günergun

Soğuk Savaş ve Bilim (2kr.)

Dr. Öğr. Üyesi Kaan Ata

Bilim Etiği (2kr.)

Doç. Dr. Rainer Brömer

\section{Seçmeli}

Tarih Boyunca Göçler (2kr.)

Dr. Öğr. Üyesi Selma Akay Ertürk

Teknoloji Tarihi 2 (2kr.)

Prof. Dr. Aytekin Çökelez

\section{8-2020 Ders Yılında Uygulanan Lisans Ders Programı}

\section{SINIF}

\section{Güz Dönemi}

Bilim Tarihine Giriş (3kr.)

Dr. Öğr. Üyesi Gaye Danışan

Eskiçağda Bilim ve Teknik 1 (3kr.)

Doç. Dr. Gaye Şahinbaş Erginöz

Avrupa'da Bilim ve Teknoloji Mirası (2kr.)

Prof. Dr. Feza Günergun

Matematik Tarihi 1 (3kr.)

Dr. Öğr. Üyesi Özkan Değer

\section{Bahar Dönemi}

Bilim ve Toplum (3kr.)

Doç. Dr. Meltem Kocaman

Eskiçağda Bilim ve Teknik 2 (3kr.)

Doç. Dr. Gaye Şahinbaş Erginöz

5 Aralık 2019'da Çin'in Wuhan kentinde başlayan ve 2020 yılında tüm dünyaya yayılan Covid-19 pandemisi sebebiyle, 6 Nisan 2020 tarihinden itibaren Edebiyat Fakültesi'ndeki diğer teorik dersler gibi Bilim Tarihi Bölümü'nün dersleri de uzaktan eğitim şeklinde verilmiştir. 
Türkiye’de Bilim ve Teknoloji Mirası (2kr.)

Matematik Tarihi 2 (3kr.)
Prof. Dr. Feza Günergun

Dr. Öğr. Üyesi Özkan Değer

\section{SINIF}

\section{Güz Dönemi}

\section{Zorunlu}

Ortaçağ İslam Dünyasında

Bilim ve Teknoloji (2kr.)

Prof. Dr. Sevtap Kadıoğlu

Fizik Tarihi 1 (2kr.)

Doç. Dr. Meltem Kocaman

Bilim Tarihi Kaynak Metinleri 1 (2kr.)

Dr. Öğr. Üyesi Mehmet Sait Türkhan

Bilim Tarihçileri İçin Tarih Yazımı (2kr.)

Doç. Dr. Meltem Kocaman

Mimarlık Mirası (2kr.)

Prof. Dr. Deniz Mazlum

\section{Seçmeli}

Amerikan Silah Teknolojisi ve

Osmanlı Devleti (2kr.)

Dr. Öğr. Üyesi Metin Ünver

Eleştirel Düşünme (2kr.)

Dr. Öğr. Üyesi Murad Omay

Tarihi Coğrafya (2kr.)

Doç. Dr. Mehmet Bayartan

Madencilik Tarihi (2kr.)

Dr. Öğr. Üyesi Selma Akay Ertürk

Felsefi ve Eleştirel Düşünce (2kr.)

Prof. Dr. Cengiz Çakmak

Kültürel Etkinlikler 1 (2kr.)

\section{Bahar Dönemi}

\section{Zorunlu}

Rönesans’ta Bilim (2kr.)

Fizik Tarihi 2 (2kr.)

Bilim Tarihi Kaynak Metinleri 2 (2kr.)
Dr. Öğr. Üyesi Gaye Danışan

Doç. Dr. Meltem Kocaman

Dr. Öğr. Üyesi Mehmet Sait Türkhan 
Bilim ve Medya (2kr.)

Eczacılık Tarihi (2kr.)

Eskiçağda Bilim Semineri (2kr.)

\section{Seçmeli}

Bilim ve Sanat (2kr.)

Akıl Yürütme ve Temellendirme (2kr.)

Kültürel Etkinlikler 2 (2kr.)
Prof. Dr. Belkıs Ulusoy

Doç. Dr. Gaye Şahinbaş Erginöz

Doç. Dr. Gaye Şahinbaş Erginöz

Prof. Dr. Şefik Görkey

Dr. Öğr. Üyesi Murad Omay

\section{SINIF}

\section{Güz Dönemi}

\section{Zorunlu}

Bilim Felsefesi (2kr.)

Dr. Öğr. Üyesi Vedat Kamer

Osmanlı Türkiye'sinde Bilim 1 (2kr.)

Yerbilimleri Tarihi (2kr.)

Aydınlanma Çağında Bilim (2kr.)

Prof. Dr. Feza Günergun

Prof. Dr. Ferhat Özçep

Dr. Öğr. Üyesi Kaan Ata

Bilgisayarların Tarihi (2kr.)

Dr. Öğr. Üyesi Kaan Ata

Seçmeli

Coğrafya Tarihi (2kr.)

Doç. Dr. Muzaffer Bakırcı

Kültür Bilimleri Felsefesi (2kr.)

Prof. Dr. Ayhan Bıçak

Kültürel Etkinlikler 3 (2kr.)

\section{Bahar Dönemi}

\section{Zorunlu}

Bilim Kurumlarının Tarihsel Gelişimi (2kr.) Prof. Dr. Sevtap Kadıoğlu

Osmanlı Türkiye'sinde Bilim 2 (2kr.)

Doç. Dr. Meltem Kocaman 
Yakınçağda Avrupa'da Bilim (2kr.)

Sağlık Tarihi (2kr.)

Haritacılık Tarihi (2kr.)

\section{Seçmeli}

Bizans’ta Bilim (2kr.)

Ortaçağ Avrupasında Tıp (2kr.)

Medeniyet Tarihi (2kr.)

Kültürel Etkinlikler 4 (2kr.)

\section{SINIF}

\section{Güz Dönemi}

\section{Zorunlu}

Sanayi Devrimi (2kr.)

Astronomi Tarihi 1 (2kr.)

Cumhuriyet Türkiyesi'nde Bilim (2kr.)

Biyoloji Tarihi (2kr.)

Osmanlı ve Bilim Semineri (2kr.)

\section{Seçmeli}

Teknoloji Tarihi 1 (2kr.)

Temel Bilimler ve Bilimsel

Düşüncenin Gelişimi (2kr)

Etik ve Estetik (2kr.)

\section{Bahar Dönemi}

\section{Zorunlu}

Astronomi Tarihi 2 (2kr.)
Doç. Dr. Meltem Kocaman

Prof. Dr. Şefik Görkey

Prof. Dr. Cengizhan İpbüker

Prof. Dr. Feza Günergun

Prof. Dr. Şefik Görkey
Prof. Dr. Feza Günergun

Dr. Öğr. Üyesi Gaye Danışan

Prof. Dr. Sevtap Kadıŏlu

Prof. Dr. Sevtap Kadıoğlu

Prof. Dr. Sevtap Kadıoğlu

Prof. Dr. Aytekin Çökelez

Prof. Dr. Ahmet Fahri Özok

Prof. Dr. Enver Orman 
Kimya Tarihi (2kr.)

20.Yüzyılda Fizik Tarihi (2kr.)

Cumhuriyet ve Bilim Semineri (2kr.)

Soğuk Savaş ve Bilim (2kr.)

Bilim Etiği (2kr.)

\section{Seçmeli}

Teknoloji Tarihi2 (2kr.)

Tarih Boyunca Göçler (2kr.)
Öğr. Gör. Serap Ayaz Seyhan

Dr. Öğr. Üyesi Kaan Ata

Prof. Dr. Feza Günergun

Dr. Öğr. Üyesi Kaan Ata

Dr. Öğr. Üyesi Kaan Ata

\section{Lisansüstü Eğitim}

Ocak 2016-Aralık 2020 tarihleri arasında 1 doktora tezi ve 4 yüksek lisans tezi olmak üzere toplam 5 adet lisansüstü tez çalışması tamamlanmış olup, halen tez aşamasında olan 5 doktora ve 3 yüksek lisans öğrencisi çalışmalarına devam etmektedirler. Bilim Tarihi Bölümü Yüksek Lisans Programından mezun olanlar "Bilim Tarihi Uzmanı,” Bilim Tarihi Bölümü Doktora Programından mezun olanlar ise "Bilim Tarihi Doktoru” unvanı alırlar.

\section{Lisansüstü dersler:}

Bilim Tarihi Bölümü, 2010-2011 ders y1lından itibaren kendine ait tezli lisansüstü programını açmıştır. Temel hedefi, öğrenciye bilim tarihi konusunda ileri düzeyde eğitim vermek ve öğrencinin bağımsız bilimsel araştırma yapma yeteneğini geliştirmek olan Bilim Tarihi Lisansüstü ders programı, bilim-toplum ilişkisi ile bilimsel ve teknik mirasın önemi vurgulanacak şekilde tasarlanmıştır. Bilim Tarihi Bölümü'nün 2016-2020 yılları arasında uyguladığı yüksek lisans ve doktora ders programları aşağıdaki gibidir.

\section{6-2017 Eğitim-Öğretim Yılında Uygulanan Lisansüstü Ders} Programı

\section{YÜKSEK LİSANS}

\section{Güz Dönemi}

Bilim Devrimi (3kr-Seçmeli)

Prof. Dr. Feza Günergun

Türkiye'de Fizik Tarihi 
(19.-20. y.y.) (3kr-Seçmeli)

Eskiçağda Anadolu'da Bilim ve

Toplum (3kr-Seçmeli)

Seminer (3kr- Zorunlu)

\section{Bahar Dönemi}

Medeniyetler Aras1

Bilim Transferi (3kr-Seçmeli)

Teknolojinin Gelişim Tarihi (3kr-Seçmeli)

Türkiye’de Bilim Kurumları (3kr-Seçmeli)

İlkçağda Sağlık Bilimleri (3kr-Seçmeli)

\section{DOKTORA}

\section{Güz Dönemi}

Türkiye'de Bilim Dergileri (3kr-Seçmeli)

Bilim Aletlerinin

Tarihsel Gelişimi (3kr-Seçmeli)

Türk Bilim Literatürü I (3kr-Seçmeli)

Cumhuriyet Dönemi

Bilim Politikaları (3kr-Seçmeli)

Seminer (3kr- Zorunlu)

\section{Bahar Dönemi}

Bilim Tarihi Yazıcılığı (3kr-Seçmeli)

Tekstil Tarihi (3kr-Seçmeli)

Türk Bilim Literatürü II (3kr-Seçmeli)

Cumhuriyet Dönemi

Bilim İnsanları (3kr-Seçmeli)

Seminer (3kr- Zorunlu)
Yrd. Doç. Dr. Meltem Kocaman

Yrd. Doç. Dr. Gaye Şahinbaş Erginöz

Prof. Dr. Feza Günergun

Prof. Dr. Mustafa Kaçar

Prof. Dr. Atilla Bir

Prof. Dr. Sevtap Kadıoğlu

Yrd. Doç. Dr. Gaye Şahinbaş Erginöz

Prof. Dr. Feza Günergun

Prof. Dr. Atilla Bir

Prof. Dr. Mustafa Kaçar

Prof. Dr. Sevtap Kadıŏglu

Prof. Dr. Mustafa Kaçar

Prof. Dr. Feza Günergun

Prof. Dr. Emre Dölen

Prof. Dr. Mustafa Kaçar

Prof. Dr. Sevtap Kadıŏlu

Prof. Dr. Feza Günergun 


\section{7-2018 Eğitim-Öğretim Yılında Uygulanan Lisansüstü Ders Programı}

\section{YÜKSEK LİSANS}

\section{Güz Dönemi}

Bilim Devrimi (3kr-Seçmeli)

Prof. Dr. Feza Günergun

Osmanlı Türkiyesi'nde

Fizik Tarihi (3kr-Seçmeli)

Yrd. Doç. Dr. Meltem Kocaman

Eski Anadolu'da Bilim ve Toplum (3kr-Seçmeli) Yrd. Doç. Dr. Gaye Şahinbaş Erginöz

Seminer (3kr- Zorunlu)

Prof. Dr. Feza Günergun

\section{Bahar Dönemi}

Teknolojinin Gelişim Tarihi (3kr-Seçmeli)

Prof. Dr. Atilla Bir

Bilimsel Araştırma Teknikleri ve

Yayın Etiği (3kr-Seçmeli)

Prof. Dr. Sevtap Kadıoğlu

Türkiye'de Meteorolojinin

Tarihsel Gelişimi (3kr-Seçmeli)

Prof. Dr. Sevtap Kadıoğlu

Cumhuriyet Türkiyesi'nde

Fizik Tarihi (3kr-Seçmeli)

Yrd. Doç. Dr. Kaan Ata

İlkçağda Sağlık Bilimleri (3kr-Seçmeli)

Yrd. Doç. Dr. Gaye Şahinbaş Erginöz

\section{DOKTORA}

\section{Güz Dönemi}

Türkiye'de Bilim Dergileri (3kr-Seçmeli)

Prof. Dr. Feza Günergun

Bilim Aletlerinin Tarihsel Gelişimi (3kr-Seçmeli) Prof. Dr. Atilla Bir

Klasik Dönem Osmanl1

Bilim Literatürü (3kr-Seçmeli)

Prof. Dr. Mustafa Kaçar

Cumhuriyet Dönemi

Bilim Politikaları (3kr-Seçmeli)

Prof. Dr. Sevtap Kadıoğlu 


\section{Bahar Dönemi}

Bilim Tarihi Yazıcılığı (3kr-Seçmeli)

Prof. Dr. Feza Günergun

Tekstil Tarihi (3kr-Seçmeli)

Prof. Dr. Emre Dölen

Modern Dönem Osmanlı

Bilim Literatürü (3kr-Seçmeli)

Prof. Dr. Mustafa Kaçar

Cumhuriyet Dönemi

Bilim İnsanları (3kr-Seçmeli)

Dr. Sevtap Kadığlu

Seminer (3kr- Zorunlu)

Prof. Dr. Feza Günergun

\section{8-2019 Eğitim-Öğretim Yılında Uygulanan Lisansüstü Ders Programı}

\section{YÜKSEK LİSANS}

\section{Güz Dönemi}

Bilim Devrimi (3kr-Seçmeli)

Dr. Öğr. Üyesi Gaye Danışan

Osmanlı Türkiyesi’nde Fizik Tarihi (3kr-Seçmeli) Yrd. Doç. Dr. Meltem Kocaman

Eski Anadolu'da Bilim ve Toplum (3kr-Seçmeli) Yrd. Doç. Dr. Gaye Şahinbaş Erginöz Seminer (3kr- Zorunlu) Prof. Dr. Feza Günergun

\section{Bahar Dönemi}

Teknolojinin Gelişim Tarihi (3kr-Seçmeli)

Dr. Öğr. Üyesi Gaye Danışan

Bilimsel Araștırma Teknikleri ve

Yayın Etiği (3kr-Seçmeli)

Prof. Dr. Sevtap Kadıoğlu

Türkiye'de Meteorolojinin

Tarihsel Gelişimi (3kr-Seçmeli)

Prof. Dr. Sevtap Kadıoğlu

Cumhuriyet Türkiyesi'nde

Fizik Tarihi (3kr-Seçmeli)

Yrd. Doç. Dr. Kaan Ata

İlkçağda Sağlık Bilimleri (3kr-Seçmeli)

Yrd. Doç. Dr. Gaye Şahinbaş Erginöz

\section{DOKTORA}




\section{Güz Dönemi}

Türkiye'de Bilim Dergileri (3kr-Seçmeli)

Prof. Dr. Feza Günergun

Bilim Aletlerinin Tarihsel Gelişimi (3kr-Seçmeli) Prof. Dr. Atilla Bir

Klasik Dönem Osmanlı

Bilim Literatürü (3kr-Seçmeli)

Prof. Dr. Mustafa Kaçar

Cumhuriyet Dönemi

Bilim Politikaları (3kr-Seçmeli)

Prof. Dr. Sevtap Kadıoğlu

\section{Bahar Dönemi}

Bilim Tarihi Yazıcılığı (3kr-Seçmeli)

Prof. Dr. Feza Günergun

Tekstil Tarihi (3kr-Seçmeli)

Prof. Dr. Emre Dölen

Modern Dönem Osmanlı

Bilim Literatürü (3kr-Seçmeli)

Prof. Dr. Mustafa Kaçar

Cumhuriyet Dönemi

Bilim İnsanları (3kr-Seçmeli)

Prof. Dr. Sevtap Kadıŏglu

Seminer (3kr- Zorunlu)

Prof. Dr. Feza Günergun

\section{9-2020 Eğitim-Öğretim Yılında Uygulanan Lisansüstü Ders Programı}

YÜKSEK LİSANS

Güz Dönemi

Bilim Devrimi (3kr-Seçmeli)

Dr. Öğr. Üyesi Gaye Danışan

Osmanlı Türkiyesi’nde Fizik Tarihi (3kr-Seçmeli) Yrd. Doç. Dr. Meltem Kocaman

Eski Anadolu'da Bilim ve Toplum (3kr-Seçmeli) Yrd. Doç. Dr. Gaye Şahinbaş Erginöz

Seminer (3kr- Zorunlu)

Prof. Dr. Feza Günergun

Bahar Dönemi

Teknolojinin Gelişim Tarihi (3kr-Seçmeli)

Dr. Öğr. Üyesi Gaye Danışan 
Bilimsel Araştırma Teknikleri ve

Yayın Etiği (3kr-Seçmeli)

Prof. Dr. Sevtap Kadıoğlu

Türkiye'de Meteorolojinin

Tarihsel Gelişimi (3kr-Seçmeli)

Prof. Dr. Sevtap Kadıŏlu

Cumhuriyet Türkiyesi’nde

Fizik Tarihi (3kr-Seçmeli)

Öğr. Üyesi Kaan Ata

İlkçağda Sağlık Bilimleri (3kr-Seçmeli)

\section{DOKTORA}

\section{Güz Dönemi}

Türkiye'de Bilim Dergileri (3kr-Seçmeli)

Prof. Dr. Feza Günergun

Bilim Aletlerinin Tarihsel Gelişimi (3kr-Seçmeli) Doç. Dr. Meltem Kocaman

Klasik Dönem Osmanl1

Bilim Literatürü (3kr-Seçmeli) Prof. Dr. Feza Günergun

Cumhuriyet Dönemi

Bilim Politikaları (3kr-Seçmeli) Prof. Dr. Sevtap Kadıoğlu

\section{Bahar Dönemi}

Bilim Tarihi Yazıcılığı (3kr-Seçmeli)

Tekstil Tarihi (3kr-Seçmeli)

Modern Dönem Osmanlı

Bilim Literatürü (3kr-Seçmeli)

Cumhuriyet Dönemi Bilim

İnsanları (3kr-Seçmeli)

Bilim ve Mitoloji (3kr-Seçmeli)

Seminer (3kr- Zorunlu)
Prof. Dr. Feza Günergun

Prof. Dr. Emre Dölen

Doç. Dr. Meltem Kocaman

Prof. Dr. Sevtap Kadıoğlu

Doç. Dr. Gaye Şahinbaş Erginöz

Prof. Dr. Feza Günergun 


\section{Tamamlanan doktora çalışmaları:}

1-Taha Yasin Arslan, On Altıncı Yüz Yıl Osmanlı Astronomisi ve Memluk Etkisi, ${ }^{6} 5$ Kasım 2015, Danışman: Prof. Dr. Feza Günergun.

Bu tez çalışmasında 16.yüzyıl Osmanlı astronomisi ve 13.-15. yüzyıllarda Suriye, Mısır ve Filistin'i içine alan Memluk coğrafyasındaki astronomi bilgisinin Osmanlı astronomi çalışmalarına etkisi incelenmiş; bu amaçla, kullanılan gözlem ve hesap aletlerinin özellikleri ile Osmanlı astronomlarının istinsah ve telif eserleri çerçevesinde bir değerlendirme yapılmıştır.

Dört ana bölümden oluşan bu tezin birinci bölümü "Memluk Astronomisinin Doğuşu ve Gelişimi (X.-XV. Yüzyıllar)" başlı̆̆ını taşımaktadır. Bu bölümde Memlukler öncesi dönemde ve Memlukler döneminde Mısır'daki astronomi çalışmalarına yer verilmiştir. İkinci bölüm "Memlukler Öncesinde ve Memluklerde Mîkāt İlmi: Cetveller ve Aletler (IX.-XV. Yüzyıllar)" başlığını taşımaktadır. Bu bölümde Mîkāt ilminin doğuşu ve Memlukler devrindeki çalışmaların kökenine dair bilgiler ile Memluk coğrafyasında yaşayan bazı astronomlar ve eserleri incelenmiştir. Tezin üçüncü bölümü “Osmanlı Türkiye'sinde Astronomi ve Mîkāt İlmi (XV.-XVI. Yüzyıllar)” başlığını taşımaktadır. Bu doğrultuda, mîkāt ilminde kullanılan cetveller, ayrıntılı bir biçimde incelenmiş, bu cetvellerin hazırlanışı ve nasıl kullanıldı̆̆ örneklerle açıklanmış; ayrıca mîkāt ilminin kurumları ele alınmıştır. "Memluk Mîkāt İlmi Çalışmalarının Osmanlı'ya Etkisi” başlıklı dördüncü ve son bölümde ise 13.-15. yüzyıllarda faaliyet gösteren başlıca astronomların eserlerinden bahsedilmiştir.

2-Gaye Danışan, 16. Yüzyılda Osmanlılarda Deniz Astronomisi ve Astronomi Aletleri, 16 Şubat 2016, Danışman: Prof. Dr. Feza Günergun.

İstanbul Üniversitesi Bilimsel Araştırma Projeleri Birimi tarafından desteklenmiş olan (Proje no: 22545) bu tez çalışmasında 16.yüzyılda Osmanlı denizcilerinin uyguladıkları seyir tekniklerinde astronominin yeri belirlenmiş ve kullanılması muhtemel astronomi aletlerinin neler olabileceği tespit edilmiştir. Bu amaçla deniz astronomisi ile ilgili teknik konulara yer verilmiş, İslam dünyası ve Avrupa'da 16.yüzyıla kadar yapılmış astronomi çalışmalarında denizcilik aktivilerinin yeri ele alınmış ve 15.-16.yüzyıllarda Osmanlı'da kullanılmış olan seyir teknikleri, astronomi aletleri ve denizcilik ile ilgili eserler incelenmiştir.

Tez altı ana bölümden oluşmaktadır. "Denizcilikte Kullanılan Astronomi Kavramları" başlıklı ilk bölümde gökküre üzerindeki daireler, göksel ve coğrafi koordinat sistemleri,

6 Taha Yasin Arslan'ın doktora tezi, Osmanlı Bilimi Araştırmaları'nın c. 16, sayı 2, 2015 nüshasının basımı sırasında henüz tamamlanmamış olduğundan, derginin aynı sayısında yer alan "İstanbul Üniversitesi Edebiyat Fakültesi Bilim Tarihi Bölümü’nün 2010-2015 Yılları Arasındaki Çalışmaları” başlıklı faaliyet raporunda, sürdürülmekte olan doktora çalışmaları içinde belirtilmiş ama içeriğine yer verilememiştir. Bu sebeple, 20162020 faaliyetlerini kapsayan bu raporda, Taha Yasin Arslan'ın tez çalışmasının içeriğine yer verilmiştir. 
gökcisimlerinin hareketleri ve zaman birimleri konularına yer verilmiştir. "İslam Dünyasında ve Avrupa'da Astronomi” başlıklı ikinci bölümde 16.yüzyıl öncesinde İslam coğrafyası ve Avrupa'daki astronomi çalışmaları ele alınmıştır. Üçüncü bölümde “Akdeniz ve Hint Okyanusunda Kullanılan Seyir Teknikleri ve Astronomi Aletleri” başlı̆̆ ve Hint Okyanusundaki coğrafi koşullar, seyir teknikleri ve denizcilerin kullandıkları astronomi aletleri incelenmiştir. "Osmanlı Denizciliğinde Astronomi Uygulamaları” başlıklı dördüncü bölümde Osmanlı denizciliğinde kullanılan ölçü birimleri, denizcilerin yıldızlar, ay konakları ve gel-git bilgisi, konum ve yön tayinleri hakkındaki bilgilerine yer verilmiştir. Beşinci bölümde "Osmanlı Denizciliğinde Zaman ve Takvim Bilgisi” başlığı altında Osmanlı denizcilik eserlerinde zaman hesabı ve takvim bilgisi konusu incelenmiştir. Altıncı ve son bölümde ise Osmanlı'da denizcilik ile ilgili eserlerde geçen astronomi aletlerine yer verilmiştir.

\section{Tamamlanan yüksek lisans çalışmaları:}

1-Zekeriya Duru, Kerim Erim'in Matematik Çalışmalarının Bilim Tarihi Açısından Değerlendirilmesi, 10 Ocak 2017, Danışman: Prof. Dr. Feza Günergun.

$\mathrm{Bu}$ tez çalışmasında Kerim Erim'in Türkiye'deki matematik araştırmaları ve matematik eğitimi içindeki yerinin belirlenmesi amacıyla ülkemizdeki matematik dergileri, matematikçilerimizin yayınları ve Kerim Erim'in özgün matematik çalışmaları incelenmiş ve değerlendirilmiştir.

Tez üç ana bölümden oluşmaktadır. “1900-1933 Yılları Arasında Türkiye'deki Matematik Çalışmaları” başlığını taşıyan ilk bölümde Darülfünun ve Mühendis Mekteb-i Âlisi’ndeki matematik eğitimine, ayrıca dönemin Türk matematikçilerinden Salih Zeki, Mehmet Nadir, Hüsnü Hamid Saylan ve Mustafa Salim Tunakan'ın matematik ile ilgili eserlerine yer verilmiştir. "Kerim Erim'in Biyografisi ve Akademik Yaşamı” başlıklı ikinci bölümde Kerim Erim'in hayatına ve akademik faaliyetlerine yer verilirken, "Kerim Erim'in Yayınları" başlıklı üçüncü ve son bölümde ise Kerim Erim’in tüm yayınları incelenmiştir.

\section{2-Gürsel Aksoy, Aristoteles'e Atfedilen Kitâbü'n-Nebât'ın Şamlı Nikolaos Yorumu,} 25 Haziran 2019, Danışman: Doç. Dr. Gaye Şahinbaş Erginöz.

Bu tez çalışmasında, Aristoteles’e atfedilen ve günümüze sadece 10. Yüzyıla ait Arapça çevirisi ulaşan Kitâbü'n-Nebât'ın hem Aristoteles'e aidiyeti incelenmiş hem de bilim tarihindeki yeri ve önemi ortaya konmuştur. Bu amaçla, eserin özellikle İslam botanik tarihi ile ilgili öneminin yanısıra, Ortaçağ Avrupa’sındaki etkisi de değerlendirilmiştir.

Tez çalışması üç ana bölümden oluşmaktadır. “Kitâbü’n-Nebât ve Bilim Tarihindeki Yeri” başlığını taşıyan ilk bölümde Kitâbu'n-Nebât'ın İslam ve Avrupa bilim tarihi içindeki yeri 
ele alınmıştır. Tezin “Kitâbü’n-Nebât'ın Birinci Makalesinde Aristoteles Öncesi Botanik” başlıklı ikinci bölümü, Kitâbu'n-Nebât metninin ilk makalesinin analiz ve yorumundan oluşmaktadır. “Kitâbü'n-Nebât'ın İkinci Makalesinde Peripatetik Botanik” başlıklı üçüncü ve son bölüm ise, Kitâbu'n-Nebât metninin ikinci makalesinin analiz ve yorumundan oluşmaktadır. Bu tez çalışmasının üç ana bölümünden sonra gelen Ekler kısmında Kitâbü’nNebât' 'n Türkçe çevirisi yapılmış; ayrıca bu çeviri için kullanılan yazma ve eserler hakkında bilgi verilmiştir. Ekler kısmında ise, oluşturulan Açıklamalı Sözlük yer almaktadır.

\section{3-Tuğba Cantürk Yılmaz, Osmanlı'dan Cumhuriyet Türkiyesi'ne Bilim İnsanı} Kimliğinin Değişimi (1839-1946), 9 Temmuz 2019, Danışman: Dr. Öğretim Üyesi Kaan Ata.

$\mathrm{Bu}$ tez çalışmasında Tanzimat'tan Cumhuriyet'in ilk yıllarına kadar uzanan dönemde bilim insanı kimliğinin değişimi temelinde, modern bilimlerin Türkiye’ye giriş süreci ele alınmıştır. $\mathrm{Bu}$ doğrultuda ülkemizde 1839-1946 yılları arasında bilim insanını besleyen unsurlardaki değişimler üzerinde durulmuş; modern bilim insanı kimliğine temel oluşturacak başlica isimler ve kurumlar incelenmiştir.

Tez çalışması üç ana bölümden oluşmaktadır. Tezin birinci bölümü "Bilim ve Bilim İnsanı Konusunda Tanımlar” başlığını taşımaktadır. Bu bölümde genel olarak bilim insanı kimliği, bilimde meslekleşme ve bilim insanının ihtiyaçları üzerinde durulmuştur. “'Osmanlı'dan Cumhuriyet Türkiye'sine Bilimi Etkileyen Faktörler” başlıklı ikinci bölümde Tanzimat ile birlikte bilim anlayışındaki değişim, medrese yapısından modern üniversitelerin kurulmasına geçiş ve 1933 ve 1946 üniversite reformları ele alınmıştır. Tezin üçüncü bölümü “Osmanlı'dan Cumhuriyet'e Bilim İnsanı Kimliğinin Kökenleri” başlığını taşımaktadır. Bu son bölümde âlim-ulema, münevver, entelektüel ve aydın kavramları irdelenmiş, ayrıca bilim insanı kimliği çerçevesinde bazı önemli bilim insanlarının (Başhoca İshak Efendi, Mühendis Seyyid Mustafa, Münif Paşa, Salih Zeki ve Nüzhet Gökdoğan) çalışmalarına yer verilmiştir.

4-Gökçe Toprak, Türkiye'de Cumhuriyet Döneminde Doğa Bilimleri ve Uygulanışı (1923-1946), 10 Eylül 2019, Danışman: Doç. Dr. Gaye Şahinbaş Erginöz.

Bu tezin amacı 1923-1946 yılları arasında Türkiye'de botanik, zooloji ve jeoloji alanlarındaki gelişmeler çerçevesinde, doğa bilimleri anlayışındaki değişimin incelenmesidir. Cumhuriyetin ilk yıllarında Türkiye'de doğa bilimleri alanında yapılan çalışmalar ve bu çalışmaların toplum üzerindeki etkilerinin değerlendirilebilmesi amacıyla ilk, orta ve yükseköğretim kurumlarının ders içerikleri, enstitülerde yapılan çalışmalar, yayınlar ve bunların iktisadi ve sosyal hayattaki yansımaları ele alınmıştır.

Tez çalışması üç ana bölümden oluşmaktadır. Tezin "Cumhuriyet Döneminde İlk ve Ortaöğretim Düzeyindeki Kurumlarda Doğa Bilimleri” başlığını taşıyan ilk bölümünde 
ilk ve ortaöğretim kurumlarında ve köy enstitülerinde doğa bilimleri ile ilgili faaliyetler, ders programları ve okutulan ders kitaplarının yanısıra, orta dereceli okullar için hazırlanan bilim dergilerinde yer alan doğa bilimleri konusundaki makaleler araştırılmıştır. İkinci bölüm “Cumhuriyet Döneminde Yükseköğretim Kurumlarında Doğa Bilimleri” başlığını taşımaktadır. Bu bölümde Darülfünun'da, İstanbul Üniversitesi’nde ve Ankara Yüksek Ziraat Enstitüsü'nde botanik, zooloji ve jeoloji ile ilgili faaliyetler ve adı geçen kurumların süreli yayınlarında yer alan doğa bilimleri alanına ait makaleler incelenmiş ve değerlendirilmiştir. Tezin, “Cumhuriyet Döneminde Popüler Bilim Dergilerinde Doğa Bilimleri” başlıklı üçüncü ve son bölümünde ise popüler bilim dergiciliğinin tarihsel arka planı hakkında bilgi verildikten sonra Cumhuriyetin ilk yıllarında yayımlanmaya başlayan üç popüler bilim dergisindeki (Maddiyat, Fen Âlemi, Tabiat Âlemi) doğa bilimleri ile ilgili yazılar incelenmiştir.

\section{Sürdürülmekte olan doktora çalışmaları: ${ }^{7}$}

1-Kaan Üçsu, Tarihsel Bağlamında Coğrafyacı Ebu Bekir Efendi (ö. 1691) ve Atlas Maior Tercümesi, Başlama tarihi: 2014, Danışman: Prof. Dr. Feza Günergun.

2-Atilla Polat, Matrakçı Nasuh'un Umdet'ül-Hisâb Adlı Eserinin Matematiksel Açıdan Değerlendirilmesi, Başlama tarihi: 2014, Danışman: Prof. Dr. Feza Günergun.

3-Alper Atasoy, Osmanlı Devleti’nde Modern Mekanik Biliminin Gelişimi (10. Yüzyıl), Başlama tarihi: 2019, Danışman: Prof. Dr. Sevtap Kadığlu.

4-Barışcan Ersöz, Türkiye'de Tarımı Geliştirme Politikaları Çerçevesinde Kurulan Islah Enstitülerinde Genetik Uygulamaları, Başlama tarihi: 2015, Danışman: Prof. Dr. Sevtap Kadıŏlu.

5-Zeynep Öztürk, Euklides Dışı Geometriler: Ortaya Çıkışı, Matematik ve Düşünce Tarihindeki Yeri, Başlama tarihi: 16 Şubat 2017, Danışman: Prof. Dr. Sevtap Kadıŏglu.

\section{Sürdürülmekte olan yüksek lisans çalışmaları: ${ }^{8}$}

1- Solmaz Ceren Özdemir, 19. Yüzyıl Osmanlı Astronomisinde Tutulma Hesapları ve Gözlem, Başlama tarihi: 8 Kasım 2018, Danışman: Dr. Öğr. Üyesi Gaye Danışan.

7 Bu faaliyet raporu hazırlanırken, Bilim Tarihi doktora programının ders aşamasını tamamladıkları halde, henüz tez başlıkları belirlenmemiş olan iki öğrenciye (Zekeriya Duru, Sercan Ayişin) bu listede yer verilememiştir. Ancak Sercan Ayişin'in doktora tez danışmanı Prof. Dr. Feza Günergun ve Zekeriya Duru'nun doktora tez danışmanı Prof. Dr. Sevtap Kadığlu olarak belirlenmiştir.

8 Bu faaliyet raporu hazırlanırken, Bilim Tarihi yüksek lisans programının ders aşamasını tamamladıkları halde, henüz tez başlıkları belirlenmemiş olan üç öğrenciye (Fırat Kahraman Aykara, Mehmet Gök, Kaan Kıvanç Dilli) bu listede yer verilememiştir. Ancak Fırat Kahraman Aykara (19. Yüzyıl Osmanlıca Süreli Yayınlarında Batılı Bilim İnsanı İmgesi) ve Mehmet Gök'ün (Matematikçi Mehmed İzzet Bey) yüksek lisans tez danışmanı Doç. Dr. Meltem Kocaman, Kaan Kıvanç Dilli’nin ise Dr. Öğr. Üyesi Kaan Ata olarak belirlenmiştir. 
2- Özge Hazar, Darüşşafaka'nın Doğa Tarihi Kolleksiyonunun Bilim Tarihi Açısından Değerlendirilmesi, Başlama tarihi: Ekim 2019, Danışman: Prof. Dr. Feza Günergun.

3- Yunus Emre Fenerci, İstanbul Üniversitesi Fen Fakültesi Jeofizik Enstitüsüınün Kuruluşu ve Türkiye'de Jeofizik Bilim Dalının Gelişmesine Katkısı (1926-1977), Başlama tarihi: 20 Şubat 2020, Danışman: Dr. Öğr. Üyesi Kaan Ata.

\section{Bilim Tarihi Bölümü’nün 2016-2020 yılları arasında düzenlediği sergi, konferans ve kongreler}

\section{Uluslararası Bilim Aletleri Sempozyumu ve Bilginin İzinde Sergisi}

Bilim Tarihi Bölümü, 26-30 Eylül 2016 tarihleri arasında, Uluslararası Bilim ve Teknoloji Tarihi ve Felsefesi Birliği’nin (IUHPST) Bilim Aletleri Komisyonu (SIC) ile işbirliği içinde İstanbul'da uluslararası bir sempozyum düzenlemiştir. Çok sayıda yerli ve yabancı bilim insanının katıldığı bu sempozyum, ${ }^{9}$ Bilim Aletleri Komisyonu'nun 35. Sempozyumu idi. ${ }^{10}$ $\mathrm{Bu}$ sempozyumla eşzamanlı olarak bir sergi düzenlendi. Bilim Tarihi Bölümü başkanı Prof. Dr. Feza Günergun'un küratörlüğünde, Bilim Tarihi Bölümü tarafından, İstanbul Üniversitesi’ndeki değişik birimlerin de katkılarıyla hazırlanan Bilginin İzinde: İstanbul Üniversitesi Koleksiyonlarından Bilimsel Aletler, Yazmalar, Baskılar sergisinde, ülkemizdeki bilgi arayışı serüveninde etkili olan çeşitli bilim aletleri ve eserlerden örnekler sergilenmiştir. Sergi II. Bayezid Türk Hamam Kültürü Müzesi’nde üç ay boyunca (26 Eylül-26 Aralık 2016 tarihleri arasında) ziyaretçilere açık kalmıştır. ${ }^{11}$ Sergi, İstanbul'daki ilk ve ortaöğretim okullarının ilgi odağı olmuştur. Serginin, İngilizce ve Türkçe olarak hazırlanmış kataloğu da 2016 yılında yayımlanmıştır. ${ }^{12}$

9 Sempozyum ve programı hakkında detaylı bilgi için bkz. Gaye Danışan Polat, "35. Uluslararası Bilim Aletleri Sempozyumu: Doğu ile Batı Arasında Bilim Aletleri (İstanbul, 26-30 Eylül 2016)," Osmanlı Bilimi Araştırmaları 18, 2 (2017): 93-97; Neil Brown, “XXXVth Scientific Instrument Symposium,” Osmanlı Bilimi Araştırmaları 18, 2 (2017): 104-115.

10 Sempozyumda sunulan bidirilerden bir seçki için bkz. Neil Brown, Silke Ackermann ve Feza Günergun (editörler), Scientific Instruments between East and West (Leiden-Boston: Brill, 2019), 283 s. Bu kitap hakkındaki bir tanıtım için bkz. Atilla Bir, "Bilimsel aletlerin Doğu ile Batı arasındaki yolculuğu," Osmanlı Bilimi Araştırmaları 21, 2 (2020): 423-426.

11 Bilginin İzinde sergisi ve kataloğu için bkz. William R. Shea, "Feza Günergun (ed.), Pursuing Knowledge. Istanbul, 2016, pp.149," Archives Internationales d'Histoire des Sciences, 66, 176 (2016): 28-50; Nur Banu Çetinkaya, "Bilginin İzinde: İstanbul Üniversitesi Koleksiyonlarından Bilimsel Aletler, Yazmalar, Bask1lar (İstanbul, 26 Eylül - 26 Aralık 2016)," Osmanlı Bilimi Araştırmaları 18, 2 (2017): 116-118.

12 Feza Günergun (ed.), Pursuing Knowledge, Scientific Instruments, Manuscripts and Prints from Istanbul University Collections/Bilginin İzinde-İstanbul Üniversitesi Koleksiyonlarından Bilimsel Aletler, Yazmalar, Baskılar (İstanbul, 2016). 


\section{Bilim Tarihi Bölümü'ne davet edilen bilim insanlart tarafindan verilen konferanslar}

* Prof. Dr. Atilla Bir, (İstanbul Teknik Üniversitesi emekli öğretim üyesi ve Fatih Sultan Mehmet Vakıf Üniversitesi Bilim Tarihi Bölümü öğretim üyesi), "Takiyüddin er-Rasıd (1521-1585) ve Carl Friedrich Gauss’un (1777-1855) İlkokul Cezası,” 21 Mart 2019. ${ }^{13}$

* Dr.-Ing. Emir Öngüner, "Halide ve Cahit Arf'1n Almanya Mektupları: Alman Matematikçi Helmut Hasse'nin Hususi Evraklarında Türk-Alman İlişkileri (1939- 1975),” 29 Nisan 2019. ${ }^{14}$

* Prof. Dr. Emre Dölen, (Marmara Üniversitesi emekli öğretim üyesi), "Periyodik Çizelgenin 150 Yıllık Öyküsü,, 21 Kasım 2019. ${ }^{15}$

Yukarıda listelenen konferansların dışında, Bilim Tarihi Bölümü’nü konuk araştırmacılar (Dominique Bernard, Şeref Etker) ziyaret etmiş, öğretim üyesi ve uzmanlar bölüm öğrencilerine özel seminerler vermişlerdir (Mehmet Alper Yalçınkaya, Mert Sandalcı). ${ }^{16}$

\section{Bilim Tarihi Bölümü öğrencileri tarafindan düzenlenen kongreler}

Bilim Tarihi Bölümü öğrencileri tarafından her yıl "Bilim Tarihi Bölümü Öğrenci Kongresi” adı altında, bölüm akademisyenlerinin danışmanlığında bir öğrenci kongresi düzenlenmektedir. İlki 15 Mayıs 2015 tarihinde Edebiyat Fakültesi Kurul Odasında düzenlenen kongrenin ${ }^{17}$ ikincisi 3 Mayıs 2016 tarihinde İ.Ü. Kongre Merkezinde gerçekleştirilmiştir. Üçüncü kongre 5 Mayıs 2017 tarihinde, dördüncü kongre ise 10 Mayıs 2018 tarihinde düzenlenmiştir. İ.Ü. Bilim Tarihi Bölümü V. Öğrenci Kongresi 10 Mayıs 2019 tarihinde İ.Ü. Edebiyat Fakültesi Kurul Odasında gerçekleştirilmiştir. 8 Mayıs 2020 tarihinde yapılması planlanan altıncı kongre, Covid-19 pandemisi sebebiyle yapılamamıştır.

Bugüne kadar, dördüncü öğrenci kongresi dışındaki diğer kongreler hakkında çeşitli tanıtıcı yazılar ${ }^{18}$ yayımlanmış olduğundan, burada sadece dördüncü kongre (2018)

13 Prof. Dr. Atilla Bir tarafından verilen bu konferans hakkında bkz. "İstanbul Üniversitesi Edebiyat Fakültesi Bilim Tarihi Bölümü 2018-2019 Seminer, Konferans, Ziyaret ve Buluşmaları," Osmanlı Bilimi Araştırmaları 20, 2 (2019): 173-174.

14 Dr.-Ing. Emir Öngüner tarafından verilen bu konferans hakkında bkz. a.g.m., s. 175-176.

15 Prof. Dr. Emre Dölen tarafından verilen bu konferansın tanıtımı hakkında bkz. Elif Çınar Esatoğlu, "İstanbul Üniversitesi Bilim Tarihi Bölümünde Konferans: "Periyodik Çizelgenin 150 Yıllık Öyküsü," Osmanlı Bilimi Araştırmaları 21, 1 (2020), 219-223.

16 Bu bilimsel ziyaretler hakkında detaylı bilgi için bkz. "İstanbul Üniversitesi Edebiyat Fakültesi Bilim Tarihi Bölümü 2018-2019 Seminer, Konferans, Ziyaret ve Buluşmaları," Osmanlı Bilimi Araştırmaları 20, 2 (2019), 171-179.

17 Bilim Tarihi Bölümü öğrencileri tarafından düzenlenen ilk kongrenin programı için bkz. Gaye Şahinbaş Erginöz, “İstanbul Üniversitesi Edebiyat Fakültesi Bilim Tarihi Bölümü’nün 2010-2015 Yılları Arasındaki Çalışmaları," Osmanlı Bilimi Araştırmaları 16, 2 (2015): 94-96.

18 Solmaz Ceren Özdemir, "II. İstanbul Üniversitesi Edebiyat Fakültesi Bilim Tarihi Bölümü Öğrenci Kongresi," 
tanıtılacaktır. Bu kongreye Bilim Tarihi Bölümü öğrencileri yanında, Marmara Üniversitesi Tıp Fakültesi Deontoloji ve Tıp Tarihi Anabilim Dalı Başkanı Prof. Dr. Şefik Görkey’in desteğiyle, Marmara Üniversitesi Tıp Fakültesi öğrencileri de bildirili olarak katılmışlardır. Bilim Tarihi Bölümü IV. Öğrenci Kongresi'ne katılanların isimleri ve sunum başlıkları şöyledir:

1. Oturum (10.15-11.15)

Şeyma Ceren Sanlı, Bilimde Ortak Dil Arayışları ve Baleybelen

Elif Aslan, Jeolojinin Kısa Tarihi ve Jeolog Walther Penck'in Türkiye'deki Çalışmaları

Buse Güller, Osmanlı Kimya Laboratuvarlarında Kullanılan Aletler

2. Oturum (11.30-12.30)

Elif Pelin Yllmaz, “Gregor Baci’nin Portresi” Tablosuna Tıbbi Yaklaşım

İbrahim İnci, Rus Çarı Korkunç Ivan’ın Katlinin Tablosu ve Tıp Açısından Yorumlanması Hasan Dirlik, Osmanlı Tıbbında Hastalıklar ve Tedavi Yöntemleri

3. Oturum (14.00-15.20)

Hatice Şule Ünal, Dokuma Tezgâhlarından Ana Bilgisayarlara: Delikli Kartların Gelişiminin 250 Y1lı

Nilhan Aktaş, Delilik mi, dâhilik mi? Çift Başlı ve Gövdesiz Köpek Deneyleri

Emine Buse Yavuzcan, Bilimsel Devrimlerin Yapısı ve 17. Yüzyıl Bilim Devrimi

Elif Çınar Esatoğlu, 2. ve 14. Yüzyıllar Arasında Çin'de Haritacılık

4. Oturum (15.40-16.40)

Fevzi Kerem Taş, Theodor Rombouts’un “Şarlatan Dişçi” Tablosundaki Dişçilik Aletleri

Zeynep Meral, Rembrandt, Şaşılık ve Üç Boyutlu Görme

Çağla Tarım, Kan Alma ile İlgili bir Tablonun Yorumlanması ve Tıbbi Yaklaşım

Osmanlı Bilimi Araştırmaları 18, 1 (2016), 98-99; Solmaz Ceren Özdemir, "İstanbul Üniversitesi Edebiyat Fakültesi Bilim Tarihi Bölümü III. Öğrenci Kongresi,” Osmanlı Bilimi Araştırmaları 18, 2 (2017), 118-121; Ahmet Sanıyar, Burcu Buyurman ve Elif Çınar Esatoğlu, "İstanbul Üniversitesi Edebiyat Fakültesi Bilim Tarihi Bölümü V. Öğrenci Kongresi,” Osmanlı Bilimi Araştırmaları 20, 2 (2019): 181-184. 


\section{Bilim Tarihi Bölümü'nün süreli yayını: Osmanlı Bilimi Araştırmaları}

Türkiye'deki ilk akademik bilim tarihi dergisi olan Osmanlı Bilimi Araştırmaları / Studies in Ottoman Science (OBA), 1995 yılında Prof. Dr. Feza Günergun’un editörlüğünde yayımlanmaya başlamıştır. 2001 yılından itibaren "Hakemli Dergi” statüsünü alan ve yılda iki sayı olarak çıkarılmaya başlanan dergi, Türk bilim, teknoloji, tıp ve eczacılık tarihi konusundaki orijinal araştırma makalelerinin yanısıra, çeviri yazılar, toplantı, sergi ve yayın tanıtımlarına da yer vermektedir.

Hem basılı hem de elektronik ortamda ${ }^{19}$ yayımlanan derginin yayın dili Türkçe olup, İngilizce, Fransızca ve Almanca makaleler de kabul edilmektedir. 2016 yılına kadar TR-Dizin tarafindan ve halen EBSCOhost ve DOAJ tarafindan taranmakta ve indekslenmektedir. 2020 yılından itibaren yeniden TR-Dizin'e kabul edilmiştir. Ayrıca, İstanbul Üniversitesi Yayınevi tarafından yapılan araştırmaya göre, son on iki yıl içinde (2008-2020), (yurtiçi ve yurdışı kaynaklı) Web of Science indeksli 76 adet makalede OBA'daki makalelerden atıf üretildiği tespit edilmiştir.

Osmanlı Bilimi Araştırmaları dergisinin 2016-2020 yılları arasında basılan sayılarında yer alan araştırma makalelerinin ve diğer yazıların başlıkları ve yazar adları aşağıdadır:

\section{Cilt XVII, sayı 2, 2016}

Şinasi Acar, Atilla Bir, Mustafa Kaçar, "Osmanlı'da sivil mühendis yetiştirmek üzere açılan Hendese-i Mülkiye Mektebi"; Ebru Kayaalp, "Granting historicity to scientific objects: The analysis of the life history of "the outermost order of the muscle, back view"; Şeref Etker, "Darülfünun'a mersiye"; Bilal Yurtoğlu, "Dârüşşafaka dergisinin bilim, düşünce ve eğitim hayatımıza katkıları"; Irfan Elmacı, "Değişen müfredat ve Türkiye'de kimya mühendisliğinin tarihi”; Şeref Etker, “Dr. Jur. Et Phil. Erich Auerbach'1n İstanbul Üniversitesi ile sözleşmeleri” (çeviri).

\section{Cilt XVIII, sayı 1, 2016}

Gaye Danışan, "Osmanlı denizcileri ve serko haritası (quartier de réduction)"; Meltem Kocaman, "Kamuran Sırrı (1891-1935): Bir elektrik mühendisinin yaşam öyküsü”; Kahraman Şakul, "Osmanlıların ilk maden kömürcülüğü girişimi: Yedikumlar kömür madeni mukataası"; Barlşcan Ersöz, "The emergence of a new scientific discipline in Turkey: Genetics at Istanbul University after the 1933 University Reform"; Murat Özveri, Şinasi Acar, "Osmanlı'da bir firlatma silahı: Lobut"; Emre Dölen, "Eczacılık tarihi alanında önemli bir kitap: Farmakolog dergisinin özetli bibliyografyası ve incelmesi” (yayın tanıtımı);

19 Osmanlı Bilimi Araştırmaları'nın geçmiş sayılarının içinde yer alan araştırma makalelerine https://dergipark. org.tr/tr/pub/iuoba ve Bilim Tarihi web sayfasından (http://www.bilimtarihi.org) ulaşılabilir. 
Emre Dölen, “XII. Türk Eczacılık Tarihi Toplantısı'nın ve bir eczacılık tarihi sergisinin ardından" (bilimsel toplantı tanıtımı); Solmaz Ceren Özdemir, "II. İstanbul Üniversitesi Edebiyat Fakültesi Bilim Tarihi Bölümü Öğrenci Kongresi” (bilimsel toplantı tanıtımı); Ali Y. Baltacıoğlu, “Ali Y. Baltacıoğlu'nun "Darülfünun'a Mersiye” makalesinin yazarı Şeref Etker'e mektubu” (yazışma ve eleştiri).

\section{Cilt XVIII, sayı 2, 2017}

Serdar Soyluer, "Osmanlı Devleti'nde ağır sanayi yatırımlarına bir örnek: Yalı Köşkü demir ve makine fabrikası"; Şinasi Acar, Murat Özveri, "Bir İstanbul okçuluk menzilnâmesi”; Remzi Çavuş, "Osmanlı Devleti'nde çekirgelere karşı mücadele (1908-1918)"; Irfan Elmacı, "Osmanlı Türkiyesinde bilim akademisi kurma girişimleri ve deney" (derleme makale); Gaye Danışan Polat, "35. Uluslararası Bilim Aletleri Sempozyumu: Doğu ile Batı Arasında Bilim Aletleri (İstanbul, 26-30 Eylül 2016)"; "Programme, XXXVth Scientific Instrument Symposium 'Instruments between East and West' (Istanbul, 26-30 September 2016)"; Neil Brown, "XXXVth Scientific Instrument Symposium"; Nur Banu Çetinkaya, "Bilginin İzinde: İstanbul Üniversitesi Koleksiyonlarından Bilimsel Aletler, Yazmalar, Baskılar (İstanbul, 26 Eylül - 26 Aralık 2016)"; Cornucopia Magazine "Exhibition Pursuing Knowledge: Scientific Instruments, Manuscripts, and Prints from Istanbul University Collections"; Solmaz Ceren Özdemir, "İstanbul Üniversitesi Edebiyat Fakültesi Bilim Tarihi Bölümü III. Öğrenci Kongresi (İstanbul, 5 Mayıs 2017)"; Feza Günergun "Şeref Etker, İkinci Meşrutiyetin Tabip Örgütleri, 2017"; William R. Shea, "Feza Günergun (ed.), Pursuing Knowledge, 2016"; Şeref Etker, "Mehmet Karayaman (transkripsiyon ve değerlendirme), Sihhiye Müdüriyet-i Umumiyesi Ecza Diploma Defteri, 2016" (yayın tanıtımı); William R. Shea, "Jean-François Pérouse, Feza Günergun (eds.), Entre Trois Mers, Cartographie Ottomane et Française des Dardanelles et du Bosphore, 2016" (yayın tanıtımı); Şeref Etker, "Meriç Aybar, İbrahim Caner Türk (yay. haz.), Türk Tıp Tarihine Imtisal Bir Eser: Kafkas Cephe-i Harbinde Lekeli Humma, Bakteriyolog Server Kamil, 2016" (yayın tanitımı).

\section{Cilt XIX, sayı 1, 2017}

Gaye Danışan, "Kamal, an instrument of celestial navigation in the Indian Ocean, as decribed by Ottoman mariners Piri Reis and Seydi Ali Reis"; Fatih Artvinli, "Mecnuna ne urulur, ne sövülür!': Mazhar Osman ve yönetilemeyen bimarhaneler”; Seda Tan, “Türkiye'de sivil veteriner hekimliği eğitiminin başlangıcı konusunda bazı tespitler”; Kenan Demir, “Osmanlı ziraat dergilerinden bir örnek: Ekinci”; Berfin Melikoğlu Gölcü, Özlem Yüksel, Erhan Yüksel, "Baytar Mecmuas1/Baytarî Mecmua üzerine bir inceleme (1923-1933)"; Şeref Etker, "Natalia Bachour, Oswaldus Crollius und Daniel Sennert im frühneuzeitlichen Istanbul - Studien zur Rezeption des Paracelsismus im Werk des osmanischen Artzes Salih b. Nasrullah ibn Sallum al-Halabi, Freiburg" (yayın tanıtımı); Şeref Etker, "İskerletzade Aleksandros Mavrokordatos'un Pneumaticum Instrumentum Circulandi Sanguinis sive De Motu et Usu Pulmonum (1664) başlıklı tezinin çevirileri” (yayın tanıtımı). 


\section{Cilt XIX, sayı 2, 2018}

Ali Yusuf Baltacıoğlu, "Müderris Tevfik [Subaş1], 1879-1954"; Burcu Şen Utsukarçi, Gökçe Toprak, “Ali Ufki’nin Mecmua-i Saz ü Söz’ündeki ilaç reçeteleri”; Derya Geçili, "Yirminci yüzyıl başında Osmanlı donanması için makineci ve gemici çıraklarının yetiştirilmesi”; Mehmet Şinasi Acar, Murat Özveri, "Osmanlı'da savaş ve spor topuzları"; Irfan Elmacı, "Simyadan kimyaya Osmanlı İmparatorluğunda teknoloji” (derleme makale); Feza Günergun, "İstanbul'da mülteci ve bilim adamı olmak” (yayın tanıtımı); Şeref Etker, “Türkiye'de kimya biliminin mikrotarih araştırmalarına giriş" (yayın tanıtımı); Şeref Etker, “Öykü, Askeri Tıbbiye’den alınan bir kimyagerlik sertifikasıyla başlar” (yayın tanıtımı).

\section{Cilt XIX, 'Savaş ve Bilim’ Özel Sayısı, 2018}

Şeref Etker, "Toxicology in poisonous years: Sümum ve Tesemmümat, Damascus/Beirut 1918"; Denis Beaudouin, Dominique Bernard, "Savants français dans la Guerre mondiale 1914-1918"; Ismet Sarıbal, "Mucit mi müntehil mi? Müderris Mehmed Şakir Efendi'nin nev-icad torpidoları"; Oya Dağlar Macar, "Transportation of the wounded during the RussoTurkish War of 1877-1878"; Şeref Etker, "Bir bakterinin biyografisi- S.Paratyphi Erzincan (Neukirch)"; Bilge Karbi, "Hugo Grothe'nin Birinci Dünya Savaşı sırasında hazırladığı eserlerde Osmanlı iktisadi modernleşmesi üzerine görüşler” (derleme makale); Feza Günergun, “Birinci Dünya Savaşı’na katılan Türk öğrenci ve öğretmenler” (yayın tanıtımı).

\section{Cilt XX, sayı 1, 2019}

Feza Günergun, "İstanbul'da bir Payen aritmometresi ve Türkçe kullanım kılavuzu”; Atilla Polat, "Son dönem Osmanlı matematikçi-bürokratı Vidinli Hüseyin Tevfik Paşa'nın hayatı"; Zekeriya Duru, "Kerim Erim'in akademik yaşamı ve matematik çalışmaları"; Feza Günergun, "Paul Mentré: 1926-1928 yıllarında İstanbul'da bir Fransız matematikçimühendis"; Semiha Betül Takıcak, "Şükrü Sayan'ın "Kemmiyyât-1 Mevhûmenin Sûret-i İâesine Dair Yeni bir Nazariyye" adlı makalesi."

\section{Cilt XX, sayı 2, 2019}

M. Namık Yalçın, Gerhard Walther Penck, "Auf den Fussspuren eines deutschen Geowissenschaftlers in Istanbul (1915-1918): Prof. Dr. Walther Penck"; Atilla Polat, "Mekteb-i Harbiye nazırlarından matematikçi Mehmed Emin Paşa'nın biyografisine giriş"; Eyüp Talha Kocacık, Emre Dölen, “Osmanlı ve Cumhuriyet Türkiyesi’nde eczacı kalfalarının örgütlenme girişimleri (1912-1949)"; Derya Geçili, "Osmanlı donanması askerlerinin tayyarelerde görevlendirilmek üzere yetiştirilmesi"; Pierre Ageron, "Note sur le dessin du système de Copernic dans le manuscrit Kandilli 403" (araştırma notu); Ali Y. Baltacıoğlu, “Müderris Şükrü [Sayan (1884-1943)]” (katk1); Emre Dölen, “Prof. Dr. Remziye Hisar'ın 
anılarını ve görüşlerini içeren yeni bir kitap hakkında düşünce ve katkılar" (yayın tanıtımı); Atilla Polat, "Osmanlı biliminin tartışmalı bir yorumu üzerine" (yayın tanıtımı); Emre Dölen, "Kimya tarihi konusundaki bir kitap üzerine aykırı düşünceler" (yayın tanıtımı); Gönenç Göçmengil, Feza Günergun, "Botanik araştırmalarının Türkiye'deki tarihine bir katkı: Ulusal Botanik Bahçeleri, Arboretumlar, Herbaryumlar, Botanik Bahçeleri Çalıştayı (Düzce, 2019)" (bilimsel toplantı tanıtımı); Bilim Tarihi Bölümü, "İstanbul Üniversitesi Edebiyat Fakültesi Bilim Tarihi Bölümü 2018-2019 seminer, konferans, ziyaret ve buluşmaları"; Ahmet Sanıyar, Burcu Buyurman, Elif Çınar Esatoğulu, "İstanbul Üniversitesi Edebiyat Fakültesi Bilim Tarihi Bölümü V. Öğrenci Kongresi (İstanbul, 10 Mayıs 2019)” (etkinlik tanıtımı); Elif Çınar Esatoğlu, "İstanbul Üniversitesi Bilim Tarihi Bölümü Öğrencileri “Cezeri’nin Olağanüstü Makineleri" Sergisinde" (etkinlik tanıtımı).

\section{Cilt XXI, sayı 1, 2020}

Eyüp Talha Kocacık, Emre Dölen, “İki Dünya Savaşı arasında Türkiye’de zehirli gazlardan korunma kursları ve yasal düzenlemeler"; Şeref Etker, "Kimyager Kevkep Reşat [Duruöz] Hanımın kısa süren meslek yaşamı"; Cem Hakan Başaran, Nilüfer Demirsoy, "Operatör Doktor Ömer Vasfi Aybar ve Ankara'da yayımladığı Türk Hekimi dergisi”; Bilal Yurtoğlu, “İbrahim Edhem Paşa'nın 'Medhal-i 'İlm-i Jeoloji' başlıklı makalesi”; Nuran Yıldırım, "Prof. Dr. Bedi N. Şehsuvaroğlu, Türk tıp tarihi ve kültürüne katkıları"; Pierre Ageron, "Les versions turque et arabe du manuel d'utilisation de l'arithmomètre de Thomas" (katk1); Şeref Etker, "Yurtdışında kimya doktorası yapan Türklere ek" (katkı); İdris Çakıroğlu, "Fuad Köprülü’nün “Türk Musikisi Tarihi” başlıklı yazısının çevirisi” (çeviri); Elif Çınar Esatoğlu, "İstanbul Üniversitesi Bilim Tarihi Bölümünde Konferans: "Periyodik Çizelgenin 150 Yıllık Öyküsü” (konferans tanıtımı); Feza Günergun, “Dr. Kırımlı Aziz'in Kimya-yı Tıbbi’sinin bir kimyacı gözüyle incelenmesi” (yayın tanıtımı).

\section{Cilt XXI, sayı 2, 2020}

ŞerefEtker, "İstanbul'un ilk verem savaşımı derneği: Ligue contre la Tuberculose (Phitisie pulmonaire) de Constantinople"; Atilla Polat, Halime Mücella Demirhan Çavuşoğlu, "Mehmed Said Efendi’nin Misâha Risâlesi"; Zeynep Sabancı, "Kışladan araziye: 1910 Osmanlı sonbahar manevrası"; Şeyhmus Bingül, "Osmanlı Devleti’nde iletişim araçlarının kontrolü: 'Telefon tevkifleri'”; Safiye Yllmaz Erten, "Hüsnü Hamid Sayman'ın Muallimler Mecmuası'ndaki yazıları"; Ceren Gülser Illikan Rasimoğlu, “Tıp tarihyazımı: Karşıtlıklar, etkileşimler" (derleme makale); Yusuf Akçay, "Mehmet Refik Fenmen'in Aynştayn Nazariyyesi: Mekân Zaman ve Kütle Mefhumlarının Tebeddülü adlı eseri (Latin harfli metin ve sözlük)" (çeviri); Atilla Polat, "Cem Tezer’in Aziz Hatırasına..." (nekroloji); Şeref Etker, Gönenç Göçmengil, "Sanal tarih yazıcılığının sorunları: Prof. Ohannes Manisacıyan ve Merzifon Anadolu Koleji Müzesi” (yayın tanıtımı); Atilla Bir, "Bilimsel aletlerin Doğu 
ile Batı arasındaki yolculuğu" (yayın tanıtımı); Gaye Danışan, "A scientific tour among the mathematical instruments in the collection of the Bibliothèque nationale de France" (yayın tanıtımı); Feza Günergun, “Batlamyus'un Coğrafya'sının yeni bir tıpkıbasımı: Bizans İstanbulunda kopyalanan Codex Seragliensis Gİ 57" (yayın tanıtımı); Gaye Erginöz, “Aristoteles'e atfedilen bir mineraloji kitabı ve bilim tarihindeki yeri” (yayın tanıtımı); Feza Günergun, "Yazık oldu Vidinli'nin emeklerine! Hüseyin Tevfik Paşa ve "Linear Algebra" (1988) kitabının yenibasımı üzerine düşünceler” (yayın tanıtımı).

\section{Bilim Tarihi Bölümü'nün Akademik Personeli: Yükseltmeler ve atamalar}

Bilim Tarihi Bölümü, 2020 yılı itibariyle iki profesör (Bölüm Başkanı Prof. Dr. Feza Günergun, Prof. Dr. Sevtap Kadığlu), ikisi “doçent” unvanına sahip (Bölüm Başkan Yardımcısı Doç. Dr. Gaye Şahinbaş Erginöz, Bölüm Başkan Yardımcısı Doç. Dr. Meltem Kocaman) dört doktor öğretim üyesi (Dr. Öğr. Üyesi Kaan Ata, Dr. Öğr. Üyesi Gaye Danışan) ve dört araştırma görevlisinden (Araş. Gör. Barışcan Ersöz, Araş. Gör. Atilla Polat ${ }^{20}$, Araş. Gör. Kaan Üçsu, Araş. Gör. Özge Hazar) oluşan on kişilik kadrosuyla faaliyetlerini sürdürmektedir. Ayrıca misafir öğretim üyeleri de verdikleri derslerle Bilim Tarihi Bölümü’nün lisans ve lisansüstü eğitimine katkıda bulunmaktadırlar. ${ }^{21}$

Prof. Dr. Feza Günergun, 22 Ocak 2018 tarihinden itibaren İstanbul Üniversitesi Edebiyat Fakültesi Bilim Tarihi Bölümü Bilim Tarihi Anabilim Dalı başkanlığını ve 9 Mayıs 2019 tarihinden itibaren de İ.Ü. Edebiyat Fakültesi Bilim Tarihi Bölümü başkanlığını yürütmeye devam etmektedir. ${ }^{22}$ Prof. Dr. Feza Günergun, 11 Şubat 2019 tarihinden itibaren İ.Ü. Sosyal Bilimler Enstitüsü Enstitü Kurul Üyesi ve 9 Mayıs 2019 tarihinden itibaren de İ.Ü. Edebiyat Fakültesi Fakülte Kurulu Üyesidir.

Prof. Dr. Sevtap Kadığ̆lu, 2010-2019 yılları arasında İ.Ü. Edebiyat Fakültesi Bilim Tarihi Bölümü başkan yardımcılığını yürütmüş; ilk defa 2014 yılında seçildiği İ.Ü. Edebiyat Fakültesi Fakülte Yönetim Kurulu Üyeliğine, 3 Mart 2020 tarihinden itibaren yeniden seçilmiştir. Ayrıca 2017-2020 yılları arasında İ.Ü. Edebiyat Fakültesi Dekan Yardımcılığı yapmış olan Prof. Kadıoğlu, 27 Mayıs 2020 tarihinden itibaren İ.Ü. Edebiyat Fakültesi Dekan Yardımcılığına ikinci defa atanmıştır.

20 Atilla Polat, 2014-2021 yılları arasında İ.Ü. Bilim Tarihi Bölümü’nde ÖYP kapsamında (Kastamonu Üniversitesi) araştırma görevlisi olarak çalışmıştır.

21 Bilim Tarihi Bölümü'nün akademik kadrosunun ve misafir öğretim üyelerinin özgeçmişleri ve bilimsel çalışmaları hakkında bkz. http://edebiyat.istanbul.edu.tr/bilimtarihi/.

22 Prof. Dr. Feza Günergun, İstanbul Üniversitesi Edebiyat Fakültesi Bilim Tarihi Bölümü'nün Anabilim Dalı'na dönüştürülmesinden sonra, 2001-2010 yılları arasında başkanlığını yürütmüş, Bilim Tarihi Anabilim Dalı’nın 2010 yılında ikinci defa bölüm haline gelmesinden sonra da bölüm başkanlığını yürütmeye devam etmiştir. Prof. Günergun, Bilim Tarihi Bölümü içinde ilk defa 2018 yılında açılan Bilim Tarihi Anabilim Dalı’nın başkanlığını 22 Ocak 2018 tarihinden itibaren yürütmektedir. 
Gaye Danışan, 10 Şubat 2018 tarihinde Doktor Öğretim Üyesi kadrosuna ve Özge Hazar, 10 Ağustos 2020 tarihinde Araştırma Görevlisi kadrosuna atanmıştır. Yrd. Doç. Dr. Gaye Şahinbaş Erginöz, Yrd. Doç. Dr. Meltem Kocaman ve Yrd. Doç. Dr. Kaan Ata'nın kadro ünvanları, 6 Mart 2018 tarihinden itibaren Dr. Öğretim Üyesi olarak değiştirilmiştir. ${ }^{23}$ Dr. Öğretim Üyesi Meltem Kocaman, 19 Nisan 2018 tarihinde ve Dr. Öğretim Üyesi Gaye Şahinbaş Erginöz, 25 Eylül 2018 tarihinde Doçent ünvanı almışlardır. 10 Mayıs 2019 tarihinden itibaren Doç. Dr. Meltem Kocaman ve Doç. Dr. Gaye Şahinbaş Erginöz, İ.Ü. Edebiyat Fakültesi Bilim Tarihi Bölümü başkan yardımcılığını yürütmektedirler.

\section{Bilim Tarihi Bölümü Akademik Personelinin 2016-2020 Yılları Arasındaki Yayınları ve Diğer Bilimsel Çalışmaları ${ }^{24}$}

\section{FEZA GÜNERGUN ${ }^{25}$}

\section{Yayınlar}

Pérouse, Jean François ve Feza Günergun (editörler). Üç Denizin Arasında Osmanlı ve Fransız Boğaz Haritaları / Entre Trois Mers - Cartographie ottomane et française des Dardanelles et du Bosphore. İzmir: Arkas Sanat Merkezi, 2016, 269 s.

Günergun, Feza ve Kaan Üçsu. “19. Yüzyıl Osmanlı Askeri Kurumlarında Boğazların Haritalanması: İstanbul Üniversitesi Koleksiyonları Üzerinden Toplu Bir Bakış / La Cartographie des Détroits dans les Institutions militaires ottomanes au XIXe siècle." $\ddot{U}_{\mathcal{C}}$ Denizin Arasında Osmanlı ve Fransız Boğaz Haritaları / Entre Trois Mers - Cartographie ottomane et française des Dardanelles et du Bosphore. Editörler: Jean François Pérouse ve Feza Günergun, 144-173. İzmir: Arkas Sanat Merkezi, 2016.

Üçsu, Kaan ve Feza Günergun. "Harita Tersimi Atlası Işı̆̆ında Osmanlı Askeri Okul Öğrencilerinin Harita Derslerine Tanıklık / Témoignage sur les Cours de Cartographie dispensés dans les Écoles militaires ottomanes au Regard du Manuel Harita Tersimi Atlast." $\ddot{U} c ̧$ Denizin Arasında Osmanlı ve Fransız Boğaz Haritaları / Entre Trois Mers - Cartographie ottomane et française des Dardanelles et du Bosphore. Editörler: Jean François Pérouse ve Feza Günergun, 204-211. İzmir: Arkas Sanat Merkezi, 2016.

Günergun, Feza (editör). Bilginin İzinde - Istanbul Üniversitesi Koleksiyonlarından Bilimsel Aletler, Yazmalar, Baskllar / Pursuing Knowledge - Scientific Instruments, Manuscripts and Prints form Istanbul University Collections. Istanbul, 2016, 149 s.

236 Mart 2018 tarih ve 30352 sayılı Resmi Gazetede yayımlanan Yükseköğretim Kanunu ile Bazı Kanun ve Kanun Hükmünde Kararnamelerde Değişiklik Yapılması Hakkında Kanuna göre (Kanun No. 7100, Kabul Tarihi: 22.02.2018) "yardımcı doçent" ibaresi "doktor öğretim üyesi”" şeklinde değiştirilmiştir. Bkz. https:// www.resmigazete.gov.tr/eskiler/2018/03/20180306-11.htm.

24 Bölüm öğretim üye ve yardımcılarının yayın faaliyetleri, İstanbul Üniversitesi Akademik Veri Yönetim Sisteminde (AVESIS) yer alan bilgilerden ve kendilerinin yazara ilettikleri listelerden istifade edilerek hazırlanmıştır.

25 https://avesis.istanbul.edu.tr/gunerfez. Erişim 4 Nisan 2021. 
Günergun, Feza. “Osmanlıların Bilgi Arayışı” Bilginin İzinde - Istanbul Üniversitesi Koleksiyonlarından Bilimsel Aletler, Yazmalar, Baskılar. Editör F. Günergun, 8-15. İstanbul, 2016.

Günergun, Feza. “Ottomans' Quest for Knowledge.” Pursuing Knowledge - Scientific Instruments, Manuscripts and Prints form Istanbul University Collections. Editör F. Günergun, 16-23. Istanbul, 2016.

Günergun, Feza. “Kronoloji / Doğu’nun Bilimi - Batı’nın Tekniği: Türkiye’de 700 Yıllık Bir Sürecin Satır Başları.” Bilginin İzinde - İstanbul Üniversitesi Koleksiyonlarından Bilimsel Aletler, Yazmalar, Basklar. Editör Feza Günergun, 24-32. İstanbul, 2016.

Günergun, Feza. “Chronology / Science from the East-Techniques from the West: Turkey's 700-Year Long Venture.” Pursuing Knowledge - Scientific Instruments, Manuscripts and Prints form Istanbul University Collections. Editör Feza Günergun, 33-41. Istanbul, 2016.

Günergun, Feza, Gaye Danışan [Polat] ve Atilla Polat, "Measuring Altitudes with and Alla Franca Instrument: The Ottoman Engineer Feyzi's Treatise on the Portable Sextant," XXXVth Scientific Instrument Symposium - Instruments between East and West - Abstracts, 27. İstanbul, 2016.

Günergun, Feza (editör). Osmanlı Bilimi Araştırmaları /Studies in Ottoman Science 17, 2 (2016).

Günergun, Feza (editör). Osmanlı Bilimi Araştırmaları /Studies in Ottoman Science 18, 1 (2016).

Günergun, Feza. "Transmitting European Science and Technology to the Empire: The Ottoman modus operandi (14th - 18th c.)." Lectures at the Moonlight Monastery on Cunda III, Summer 2017, 53-59. [Istanbul], 2017.

Günergun, Feza. "Şeref Etker, İkinci Meşrutiyetin Tabip Örgütleri." Osmanlı Bilimi Araştırmaları 18, 2 (2017): 122-124 (yayın tanıtımı).

Günergun, Feza. "La traduction de l'Abrégé de la Sphère de Jacques Robbe, Géographe du Roi de France par Petros Baronian, Drogman à Istanbul: Cem-nümâ fi fenn el-coğrafya." La Révolution française [En ligne], 12 | 2017, mis en ligne le 15 septembre 2017, Consulté le 15 septembre 2017, URL: http://lrf.revues.org/1841

Günergun, Feza (editör). Osmanlı Bilimi Araştırmaları/Studies in Ottoman Science 18, 2 (2017).

Günergun, Feza (editör). Osmanlı Bilimi Araştırmaları/Studies in Ottoman Science 19, 1 (2017). 
Günergun, Feza. “Aydın Sayılı'dan George Sarton'a Mektuplar (1935-1955)." Bilim Tarihçisi Ord. Prof. Dr. Aydın Sayılı Anma Paneli, ITÜ Fen Edebiyat Fakültesi, 14 Kasım 2018, 6-8. İstanbul: İstanbul Teknik Üniversitesi, 2018.

Günergun, Feza. "İstanbul'da Mülteci ve Bilim Adamı Olmak." Osmanlı Bilimi Araştırmaları 19, 2 (2018): 288-302 (yayın tanıtımı).

Günergun, Feza. “Birinci Dünya Savaşına Katılan Türk Öğrenci ve Öğretmenler.” Osmanlı Bilimi Araştırmaları ‘Savaş ve Bilim’ Özel Sayısı 19 (2018): 124-127 (yayın tanıtımı).

Günergun, Feza. "İstanbul'da bir Payen Aritmometresi ve Türkçe Kullanım Kılavuzu." Osmanlı Bilimi Araştırmaları 20, 1 (2019): 1-15.

Günergun, Feza. "Paul Mentré: 1926-1928 Yıllarında İstanbul'da bir Fransız Matematikçi - Mühendis.” Osmanlı Bilimi Araştırmaları 20, 1 (2019): 92-101.

Göçmengil, Gönenç ve Feza Günergun. "Botanik Araştırmalarının Türkiye'deki Tarihine Bir Katkı: Ulusal Botanik Bahçeleri, Arboretumlar, Herbaryumlar, Botanik Bahçeleri Çalıştayı.” Osmanlı Bilimi Araştırmaları 20, 2 (2019): 163-170 (çalıştay tanıtımı).

Günergun, Feza (Bilim Tarihi Bölümü adına). "Seminerler, Konferanslar, Ziyaretler, Buluşmalar.” Osmanlı Bilimi Araştırmaları 20, 2 (2019): 171-179.

Brown, Neil, Silke Ackermann ve Feza Günergun (editörler). Scientific Instruments between East and West. Leiden-Boston: Brill, 2019, 283 s.

Günergun, Feza, Gaye Danışan ve Atilla Polat, "Measuring Altitudes with and Alla Franca Instrument: The Ottoman Engineer Feyzi's Treatise on the Portable Sextant." Scientific Instruments between East and West. Editörler: Neil Brown, Silke Ackermann ve Feza Günergun, 55-79. Leiden-Boston: Brill, 2019.

Günergun, Feza (editör). Osmanlı Bilimi Araştırmaları / Studies in Ottoman Science 19, 2 (2018).

Günergun, Feza (editör). Osmanlı Bilimi Araştırmaları / Studies in Ottoman Science 19, Savaş ve Bilim Özel Sayısı (2018).

Günergun, Feza. "Convergences in and around Bursa: Sufism, Alchemy, Iatrochemistry in Turkey, 1500-1750.” Entangled Itineraries - Materials, Practices, and Knowledges across Eurasia. Editör Pamela H. Smith, 227-257. USA: University of Pittsburgh Press, 2019.

Günergun, Feza. “On Dokuzuncu Yüzyıl İstanbulu’nda İki Doğa Tarihi Müzesi: Mekteb-i Tıbbiye-yi Şahane ve Darüşşafaka Koleksiyonları.” Toplumsal Tarih sayı 311 (Kasım 2019): 48-54. 
Günergun, Feza. “Türkiye'de Bilim Tarihinin İlk Yüzyılı (1913-2013).” ITÜ sayı 84 (Eylül - Aralık 2019): 26-32.

Günergun, Feza (editör). Osmanlı Bilimi Araştırmaları / Studies in Ottoman Science 20, 1 (2019).

Günergun, Feza (editör). Osmanlı Bilimi Araştırmaları / Studies in Ottoman Science 20, $2(2019)$.

Günergun, Feza. "Dr. Kırımlı Aziz’in Kimya-yı Tıbbî’sinin Bir Kimyacı Gözüyle İncelenmesi.” Osmanlı Bilimi Araştırmaları 21, 1 (2020): 213-217 (yayın tanıtımı).

Günergun, Feza. “Batlamyus'un Coğrafyası'nın Yeni Bir Tıpkıbasımı: Bizans İstanbulunda kopyalanan Codex Seragliensis Gİ 57." Osmanlı Bilimi Araştırmaları 21, 2 (2020): 435-444 (yayın tanıtımı).

Günergun, Feza. "Yazık oldu Vidinli’nin Emeklerine! Hüseyin Tevfik Paşa ve "Linear Algebra” (1988) Kitabının Yenibasımı Üzerine Düşünceler.” Osmanlı Bilimi Araştırmaları 21, 2 (2020): 449- 457 (yayın tanitımı).

Günergun, Feza (editör). Osmanlı Bilimi Araştırmalarl / Studies in Ottoman Science 21, $1(2020)$.

Günergun, Feza (editör). Osmanlı Bilimi Araştırmaları / Studies in Ottoman Science 21, $2(2020)$.

\section{Bildiriler (özeti yayınlanmamış)}

Günergun, Feza. “İstanbul Üniversitesi Bilim Tarihi Bölümü’nün Araştırma Ekibi, Konuları ve Etkinlikleri.” STS Science Technology Studies Turkey Kuruluş Toplantısı'nda (Istanbul, Orient Institut, 3-4 Ekim 2017) sunulan bildiri.

Günergun, Feza. "Fabrication des Canons à la Fonderie de Hasköy, Istanbul au 18e siècle. Une Étude de Cas sur la Transmission des Techniques de la France vers l'Empire ottoman." Journée d'Études en l'Honneur de Patrice Bret: Sciences, Techniques, Pouvoirs, Sociétes: XVIIIe-XIXe Siècles Europe-Monde'da (Paris, Centre Alexandre Koyré, 22 Mayıs 2018) sunulan bildiri.

Günergun, Feza. “Türkiye'de Botanik Tarihi Üzerine Düşünceler.” Ulusal Botanik Bahçeleri, Arboretumlar, Herbaryumlar ve Botanik Müzeleri Çalıştayı'nda (Düzce, Düzce Üniversitesi Orman Fakültesi, 18-21 Nisan 2019) yapılan çağrılı konuşma.

Günergun, Feza. "Doğu ve Batı Dillerinden Türkçeye Çevrilen Astronomi Eserleri Üzerine Notlar (15-18. Yüzyıllar).” Prof. Dr. Abdullah Kızılırmak’1 Anma Toplantısı'nda 
(İzmir, Ege Üniversitesi Fen Fakültesi Astronomi ve Uzay Bilimlweri Bölümü, 4 Aralık 2019) sunulan bildiri.

\section{Seminer}

Günergun, Feza. "Transferring Knowledge for the Building of Modern Turkey. A survey of Students Sent to French Universities Prior to World War." CNRS Seminaire Transferts Culturels (Paris, École Normale Supérieure, 12 Ocak 2018).

\section{Bilimsel Araştırma Projeleri}

Günergun, Feza (yürütücü). “Çanakkale ve İstanbul Boğazları Haritalarının (17-19.yy) Haritacılık ve Bilim Tarihi Açısından İncelenmesi” konulu BAP projesi (Normal proje, Proje No: 44531) ) Başlangıç ve bitiş tarihi: 25.7.2014-12.12.2016.

Günergun, Feza (yürütücü). “Osmanlı İstanbulunda Deney: 18. ve 19. Yüzyıllar İçin bir Araştırma” konulu BAP Projesi (Proje No: BYP-2020-36030) Başlangıç Tarihi: 02.01.2020 (devam ediyor).

\section{SEVTAP KADIOĞLU ${ }^{26}$}

\section{Yayınlar}

Kadığlu, Sevtap. "Reforming Agriculture in Turkey: Initiatives to Organize and Disseminate Agricultural Education (1847-1928)." Cultural and Humanities Research New Rewiews and Perspectives, 78-90. Bloomington: Trafford Publishing, 2016.

Kadıoğlu, Sevtap. "Popularizing Science in Turkey World War II: A Case Study on the Journal Fen ve Teknik (Science and Technique)." Cultural and Humanities Research New Rewiews and Perspectives, 59-66. Bloomington: Trafford Publishing, 2016.

İshakoğlu Kadığlu, Sevtap ve Gaye Şahinbaş Erginöz. Belgelerle İstanbul Üniversitesi Edebiyat Fakültesi’nde Mülteci Bilim Adamları. İstanbul: İstanbul Üniversitesi Yayınevi, 2017.

Kadığlu, Sevtap ve Gaye Şahinbaş Erginöz. “İstanbul'da Bir Alman Filozof: Hans Reichenbach (1891-1953)." Hans Reichenbach, Bilimsel Felsefenin Doğuşu. Hazırlayan Osman Baran Kaplan, 13-28. Ankara: Fol Kitap, 2019.

İshakoğlu Kadığlu, Sevtap ve Gaye Şahinbaş Erginöz. Emigration of Science, A Documented History of Refugee Scientists at Istanbul University Faculty of Letters, İstanbul: İstanbul University Press, 2020.

26 https://avesis.istanbul.edu.tr/sevtapk. Erişim 4 Nisan 2021. 
http://iupresswork.com/data/kitaplar/Multeci-Bilim-Adamlari.pdf

\section{Seminer}

Kadığlu, Sevtap. “TÜBİTAK’ın Kuruluş Öyküsü”, İstanbul Üniversitesi Edebiyat Fakültesi Sosyoloji Bölümü Çarşamba Toplantıları-41'de verilen seminer, İstanbul, 2 Ekim 2019.

\section{Bilimsel Araştırma Projesi}

Kadığlu, Sevtap (araştırmacı). "İstanbul Üniversitesi Doğa Bilimleri Müzesi/Botanik Bahçesi, Herbaryum/Kurutulmuş Bitkiler Müzesi ve Zooloji Müzelerinde Bulunan Eğitim-Öğretim Araçları Koleksiyonu ve Doğa Tarihi Kitapları için Resimli ve Açıklamalı Katalog Hazırlanması”, Yükseköğretim Kurumları Destekli Proje (2014-2018, Proje yürütücüsü: Orhan Küçüker) (N.Kaya, E.Turan, O.Erol, G.Öz ile birlikte)

\section{GAYE ŞAHINBAŞ ERGINÖZ ${ }^{27}$}

\section{Yayınlar}

İshakoğlu Kadığlu, Sevtap ve Gaye Şahinbaş Erginöz. Belgelerle İstanbul Üniversitesi Edebiyat Fakültesi’nde Mülteci Bilim Adamlart. İstanbul: İstanbul Üniversitesi Yayınevi, 2017.

Şahinbaş Erginöz, Gaye. "M.Ö. 2. Bin Yılda Hitit ve Mısır Ordularının Yapısı ve Savaş Arabalar1." Aktüel Arkeoloji 61 (2018): 50-59.

Kadığlu, Sevtap ve Gaye Şahinbaş Erginöz. "İstanbul'da Bir Alman Filozof: Hans Reichenbach (1891-1953)." Hans Reichenbach, Bilimsel Felsefenin Doğuşu. Hazırlayan Osman Baran Kaplan, 13-28. Ankara: Fol Kitap, 2019.

Şahinbaş Erginöz, Gaye. “Aristoteles'e Atfedilen bir Mineraloji Kitabı ve Bilim Tarihindeki Yeri”, Osmanlı Bilimi Araştırmaları 21, 2 (2020): 221-224 (yayın tanıtımı).

İshakoğlu Kadıŏlu, Sevtap ve Gaye Şahinbaş Erginöz. Emigration of Science, A Documented History of Refugee Scientists at Istanbul University, Faculty of Letters. İstanbul: İstanbul University Press, 2020.

http://iupresswork.com/data/kitaplar/Multeci-Bilim-Adamlari.pdf 


\section{Seminer}

Şahinbaş Erginöz, Gaye. "Hititler ve Sağlık Uygulamaları.” Fatih Sultan Mehmet Vakıf Üniversitesi Bilim Tarihi Kulübü İslam Bilim Tarihi Seminerleri kapsamında Prof. Dr. Fuat Sezgin İslam Bilim Tarihi Araştırmaları Vakfı'nda verilen seminer. Gülhane- İstanbul, 15 Aralık 2017.

\section{MELTEM KOCAMAN ${ }^{28}$}

\section{Yayınlar}

Kocaman, Meltem. "Kâmuran Sirrı (1991-1935): A Biography of an Electrical Engineer." Osmanlı Bilimi Araştırmaları 18, 1 (2016): 26-38.

Kocaman, Meltem. "Some Observations on the Scientific Instrument Trade in the 19th Century Ottoman Empire." XXXVth Scientific Instrument Symposium - Instruments between East and West - Abstracts, 15. İstanbul, 2016.

Kocaman, Meltem. “Techniques, État et Société dans 1'Empire ottoman.” Histoire des Techniques: Mondes, Sociétés, Cultures (XVIe XVIIIe siècle). Yayına hazırlayanlar Guillaume Carnino, Liliane Hilaire-Pérez, Aleksandra Kobiljski, 79-100. Paris: Nouvelle Clio / Puf, 2016.

Martykanova, Darina ve Meltem Kocaman. “A Land of Opportunites: Foreign Engineers in the Ottoman Empire." Philosophy of Globalisation. Editörler: Concha Roldán, Daniel Brauer, Johannes Rohbeck, 237-251. Berlin: De Gruyter, 2018.

Kocaman, Meltem. "Scientific Instrument Retailers in Istanbul in the Nineteenth Century and, Verdoux's Optical Shop." Scientific Instruments between East and West. Editörler: Neil Brown, SilkeAckermann, Feza Günergun, 240-256. Leiden: Brill, 2019.

\section{Bildiriler (özeti yayınlanmamış)}

Kocaman, Meltem. "How did the Ottoman men of science publicly represent themselves as actors of production and circulation of knowledge in the nineteenth century? or Preface interrogation", Global Traffic: Production and Circulation of Knowledge and Ideas across the Borders atölye çalışmasında (Centro Cultural La Corrala, Madrid, 23-24 Haziran 2016) sunulan bildiri.

Kocaman, Meltem. "How did the Ottoman men of science publicly represent themselves as actors of production and circulation of knowledge in the nineteenth century?" Turkologentag 2016'da (Hamburg, Eylül 2016) sunulan bildiri.

28 https://avesis.istanbul.edu.tr/makbas. Erişim 4 Nisan 2021. 
Kocaman, Meltem. "Inclusion of scientific instruments in physics education in the 19th century Ottoman Empire.” XVIII.-XIX. Asırlarda İslam Dünyasında Bilim Eğitiminin Dönüşümü atölye çalışmasında (İstanbul, Aralık 2017) sunulan bildiri.

\section{Bilimsel Araştırma Projeleri}

Kocaman, Meltem (yürütücü ve araştırmac1). Philosophy of History and Globalisation of Knowledge. Cultural Bridges Between Europe and Latin America (WORLDBRIDGES), Avrupa Birliği 7. Çerçeve Programı (FB7-PEOPLE-2013-IRSES. GA: 612644) Projesi, 1 Mart 2014-28 Şubat 2018.

\section{KAAN ATA ${ }^{29}$}

\section{Bilimsel Araştırma Projeleri}

Ata, Kaan (araştırmacı). Philosophy of History and Globalisation of Knowledge. Cultural Bridges Between Europe and Latin America (WORLDBRIDGES), Avrupa Birliği 7. Çerçeve Programı (FB7-PEOPLE-2013-IRSES. GA: 612644) Projesi, 1 Mart 2014-28 Şubat 2018.

\section{Atölye Çalışması}

Global Traffic: Production and Circulation of Knowledge and Ideas across the Borders, Centro Cultural La Corrala, Madrid, 23-24 Haziran 2016.

\section{GAYE DANIŞAN ${ }^{30}$}

\section{Yayınlar}

[Polat] Danışan, Gaye. "Osmanlı Denizcileri ve Serko Haritası.” Osmanlı Bilimi Araştırmaları 18, 1 (2016): 1-25.

Günergun, Feza, Gaye Danışan [Polat] ve Atilla Polat, "Measuring Altitudes with and Alla Franca Instrument: The Ottoman Engineer Feyzi's Treatise on the Portable Sextant." XXXVth Scientific Instrument Symposium - Instruments between East and West - Abstracts, 27. İstanbul, 2016.

[Polat] Danışan, Gaye. "A 16th Century Ottoman Compendium of Astronomical Instruments: Admiral Seydi Ali Reis's Mir'at-1 Kainat." XXXVth Scientific Instrument Symposium - Instruments between East and West - Abstracts, 34. İstanbul, 2016. 
[Polat] Danışan, Gaye. “Anonim Bir Ruznamenin Deniz Astronomisi ve Astronomi Aletleri Açısından İncelenmesi." Fethinin 500. Yılında Cezayir, Barbaros Hayrettin Paşa ve Osmanlı Denizciliği Sempozyumu (1-3 Aralık 2016)- Özet Kitapçı̆̆ı, 27. Manisa, 2016.

[Polat] Danışan, Gaye. "Kamal, an Instrument of Celestial Navigation in the Indian Ocean, as Described by Ottoman Mariners Piri Reis and Seydi Ali Reis." Osmanlı Bilimi Araştırmaları 19, 1 (2017): 1-13.

[Polat] Danışan, Gaye. “35. Uluslararası Bilim Aletleri Sempozyumu: Doğu ile Batı Arasında Bilim Aletleri (İstanbul, 26-30 Eylül 2016)," Osmanlı Bilimi Araştırmaları 18, 2 (2017): 93-97 (yayın tanitım1).

Danışan, Gaye. "The Cylinder Dials in Ottoman Turkey: The 'Asâ-yı Musa (The Staff of Moses)." XXXVIIth Scientific Instrument Symposium (Leiden, 3-7 Eylül 2018) - Abstracts, 109-110. Leiden, 2018.

Danışan, Gaye. "Osmanlı Dönemi Astronomi Eserleri Çerçevesinde Karşılaştırmalı Bir Araştırma: Dâire-i Mu'addil'in Yapısı ve Kullanımı.” I. Uluslararası Prof. Dr. Fuat Sezgin Íslâm Bilim Tarihi Sempozyumu'nda (İstanbul, 13-15 Haziran 2019)- Abstracts, 40-41. İstanbul, 2019.

Günergun, Feza, Gaye Danışan ve Atilla Polat, "Measuring Altitudes with and Alla Franca Instrument: The Ottoman Engineer Feyzi's Treatise on the Portable Sextant," Scientific Instruments between East and West. Editörler: Neil Brown, Silke Ackermann ve Feza Günergun, 55-79. Leiden-Boston: Brill, 2019.

Danışan, Gaye. "A $16^{\text {th }}$ Century Ottoman Compendium of Astronomical Instruments: Admiral Seydi Ali Reis's Mir'at-1 Kainat.” Instruments between East and West. Editörler: Neil Brown, Silke Ackermann, Feza Günergun, 1-15. Leiden: Brill, 2019.

Danışan, Gaye. "A Scientific Tour among the Mathematical Instruments in the Collection of the Bibliothèque nationale de France (Fransız Milli Kütüphanesi Koleksiyonundaki Matematiksel Aletler Arasında Bilimsel bir Gezi)," Osmanlı Bilimi Araştırmaları 21, 2 (2020): 427-434 (yayın tanitım).

Danışan, Gaye. "Cylinder Dials in the History of Ottoman Astronomy.” The BSS Bulletin 32, 3 (Eylül 2020): 10-15.

Danışan, Gaye. "An Ottoman Volvelle found in Rūznāmā-i Shaikh Wafā.” XXXIXth Scientific Instrument Symposium (London, 14-18 September 2020) - Abstracts, 10. London, 2020. 


\section{Bildiriler (özeti yayınlanmamış)}

[Polat] Danışan, Gaye. "Anonim Bir Ruznamenin Deniz Astronomisi ve Astronomi Aletleri Açısından İncelenmesi." Fethinin 500. Yılında Cezayir, Barbaros Hayrettin Paşa ve Osmanlı Denizciliği Sempozyumu'nda (Manisa, 1-3 Aralık 2016) sunulan bildiri.

[Polat] Danışan, Gaye ve Atilla Polat. “About Ottomans' use of the cross-staff and the back-staff in navigation: How far the transmitted knowledge was implemented?" Global Traffic: Production and Circulation of Knowledge and Ideas across the Borders atölye çalışmasında (Madrid, 23-24 Haziran 2016) sunulan bildiri.

[Polat] Danışan, Gaye. "The Cylinder Dials in Ottoman Turkey: The 'Asâ-yı Musa (The Staff of Moses).” XXXVIIth Scientific Instrument Symposium'da (Leiden, 3-7 Eylül 2018) sunulan bildiri.

Danışan, Gaye. "An unusual example of Ottoman paper instruments: The calendar of Derviş Mehmed el-Hasib el-Mevlevi." Science and Technology in al-Andalus and in the Ottoman Empire, in Memoriam Prof. Fuat Sezgin başlıklı toplantıda (Madrid, 28 Haziran 2019) sunulan bildiri.

\section{Bilimsel Araştırma Projeleri}

Danışan, Gaye (araştırmacı). "Osmanlılarda Taşınabilir Astronomi Aletleri ve Kullanım Alanları: 16. Yüzyıl için Karşılaştırmalı bir Araştırma,” Oxford Üniversitesi Bilim Tarihi Müzesi'nde (The History of Science Museum, University of Oxford) Dr. Silke Ackermann danışmanlığında, ziyaretçi araştırmacı olarak yürütülen doktora sonrası araştırma Projesi (TUBITAK-2219 doktora sonrası araştırma bursu tarafından desteklenmiştir. Proje no. 1059B191600973) 28 Eylül 2017-29 Eylül 2018.

Danışan, Gaye (yürütücü). “Osmanlı astronomi tarihinde Dâ'ire-i Mu'addil'in yeri, yapısı ve kullanım alanları üzerine karşılaştırmalı bir araştırma," İ.Ü. BAP Bilimsel Yayınları Teşvik Desteği (BYP)- (2019, devam ediyor).

Danışan, Gaye (yürütücü). "Paper Instruments in the History of Ottoman astronomy," SIS (Scientific Instrument Society) araştırma desteği, 2017-2021.

Danışan, Gaye (yürütücü). “Osmanlı'da Bilimsel Etkinliğin Teorik ve Pratik Yönleri Üzerine Karşılaştırmalı Bir Çalışma: Yıllık ve Daimi Takvimler (1550-1710)”, TÜBİTAK 1003 Ar-Ge Öncelikli Alanlar Projesi (Proje no. 119K827)- (2020, devam ediyor).

\section{Çalıştay}

Oberwolfach Workshop: Mathematical Instruments between Material Artifacts and Ideal Machines: Their Scientific and Social Role before 1950, Oberwolfach, Aralık 2017. 


\section{BARIŞCAN ERSÖZ ${ }^{31}$}

\section{Yayınlar}

Ersöz, Barışcan. "The Emergence of a New Scientific Discipline in Turkey: Genetics at Istanbul University after the 1933 University Reform." Osmanlı Bilimi Araştırmalarl 18,1 (2016): 53-70.

\section{Bilimsel Araştırma Projeleri}

Ersöz, Barışcan (araştırmac1). Philosophy of History and Globalisation of Knowledge. Cultural Bridges Between Europe and Latin America (WORLDBRIDGES), Avrupa Birliği 7. Çerçeve Programı (FB7-PEOPLE-2013-IRSES. GA: 612644) 1 Mart 2014-28 Şubat 2018.

\section{ATILLA POLAT ${ }^{32}$}

\section{Yayınlar}

Polat, Atilla. "Treatises on the Description and Use of the Sector (Pergâr-1 Nisbe) in Manuscript Collections of Turkey." XXXVth Scientific Instrument Symposium - Instruments between East \& West - Abstracts, 31, İstanbul, 2016.

Günergun, Feza, Gaye Danışan [Polat] ve Atilla Polat, "Measuring Altitudes with and Alla Franca Instrument: The Ottoman Engineer Feyzi's Treatise on the Portable Sextant." $X X X V^{\text {th }}$ Scientific Instrument Symposium - Instruments between East and West - Abstracts, 27. İstanbul, 2016.

Polat, Atilla. "Osmanlı Matematikçilerinden Vidinli Hüseyin Tevfik〉in (1832-1901) Hayatı ve Eserleri Üzerine Yapılmış Çalışmalarla İlgili Bazı Değerlendirmeler.” 6. Türkiye Lisansüstü Çalışmalar Kongresi, Editörler: Kadir Budak, Sabri Eğe, Bildiri Kitabı, c. 4, 243260. Muş, Türkiye, 2017.

Polat, Atilla. "Kirkor Kömürcan and his Treatise on a Method for Multiplication: Çeprast Kaidesi (Crosswise Method)." 25th International Congress of History of Science and Technology, Abstracts, 427. Rio de Janeiro, Brezilya, 2017.

Polat, Atilla ve Ali Demirci. "Kâtip Çelebi'nin Hendese Bilen Kadısına Müşahhas Bir Örnek: Ebû Sehl Nu'mân Efendi." Sahn-ı Semân'dan Dârülfünûn'a Osmanlı 'da İlim ve Fikir Dünyası: Âlimler, Müesseseler ve Fikrî Eserler XVIII: Yüzyıl Sempozyumu, Özet Kitapçı̆̆l, 25. İstanbul, 2017.

31 https://avesis.istanbul.edu.tr/bariscan.ersoz. Erişim 4 Nisan 2021.

32 https://avesis.istanbul.edu.tr/atilla.polat. Erişim 4 Nisan 2021. 
Polat, Atilla. "Rehber-i Fünun Dergisi (1882-1883) Üzerine Bir İnceleme.” II. Uluslararası Felsefe, Eğitim, Sanat ve Bilim Tarihi Sempozyumu, Özet Kitapçı̆̆ı, 257. Muğla, Türkiye, 2017.

Polat, Atilla ve Ali Demirci. "Kâtip Çelebi'nin Hendese Bilen Kadısına Müşahhas Bir Örnek: Ebû Sehl Nu'mân Efendi." Sahn-ı Semân'dan Dârülfünûn'a Osmanlı'da İlim ve Fikir Dünyası: Âlimler, Müesseseler ve Fikrî Eserler XVIII: Yüzyıl. Editörler: Ahmet Hamdi Furat, Nilüfer Yorulmaz Kalkan, Osman Sacid Ar1, 157-177. İstanbul: Zeytinburnu Belediyesi Yayınlar1, 2018.

Polat, Atilla. "Son Dönem Osmanlı Matematikçi-Bürokratı Vidinli Hüseyin Tevfik Paşa'nın Hayatı.” Osmanlı Bilimi Araştırmaları 20, 1 (2019): 16-46.

Polat, Atilla. "Mekteb-i Harbiye Nazırlarından Matematikçi Mehmed Emin Paşa'nın Biyografisine Giriş.” Osmanlı Bilimi Araştırmaları 20, 2 (2019): 59-74.

Polat, Atilla. "Mehmed Said Efendi'nin Misâha Risalesi." I. Uluslararası Prof. Dr. Fuat Sezgin İslâm Bilim Tarihi Sempozyumu, Özet Kitapçı̆̆, 32. İstanbul, Türkiye, 2019.

Günergun, Feza, Gaye Danışan ve Atilla Polat, "Measuring Altitudes with and Alla Franca Instrument: The Ottoman Engineer Feyzi's Treatise on the Portable Sextant." Scientific Instruments between East and West. Editörler: Neil Brown, Silke Ackermann ve Feza Günergun, 55-79. Leiden-Boston: Brill, 2019.

Polat, Atilla. "Treatises on Pergar-1 Nisbe (the Sector) in Manuscript Collections in Turkey." Scientific Instruments between East and West. Editörler: Neil Brown, Silke Ackermann, Feza Günergun, 39-54. Leiden: Brill, 2019.

Polat, Atilla ve Halime Mücella Demirhan Çavuşoğlu. “15-16. Yüzyıl Türkçe Matematik Eserlerinde Geçen Manzum Bir Matematik Problemi.” Osmanlı Bilimi Sempozyumu, Özet Kitapçı̆̆ l, 35. Sakarya, Türkiye, 2019.

Polat, Atilla. "Osmanlı Biliminin Tartışmalı Bir Yorumu Üzerine." Osmanlı Bilimi Araştırmaları 20, 2 (2019): 147-156 (yayın tanıtımı).

Polat, Atilla ve Halime Mücella Demirhan Çavuşoğlu. "Mehmed Said Efendi’nin Misâha Risalesi.” Osmanlı Bilimi Araştırmaları 21, 2 (2020): 25-46.

Polat, Atilla. “Cem Tezer' in Aziz Hatırasına.” Osmanlı Bilimi Araştırmaları 21, 2 (2020): 399-401 (nekroloji). 


\section{Bildiriler (özeti yayımlanmamış)}

Polat, Atilla ve Gaye Danışan. “About Ottomans' use of the cross-staff and the backstaff in navigation: How far the transmitted knowledge was implemented?" Global Traffic: Production and Circulation of Knowledge and Ideas across the Borders atölye çalışmasında (Madrid, 23-24 Haziran 2016) sunulan bildiri.

\section{Çalıştay}

Oberwolfach Workshop: Mathematical Instruments between Material Artifacts and Ideal Machines: Their Scientific and Social Role before 1950, Oberwolfach, Aralık 2017.

\section{KAAN ÜÇSU ${ }^{33}$}

\section{Yayınlar}

Üçsu, Kaan. "Dilgan, Ahmet Hamit.” TDV İslam Ansikopedisi, Ek1: 335-336. İstanbul: Türkiye Diyanet Vakfi, 2016.

Günergun, Feza ve Kaan Üçsu. “19. Yüzyıl Osmanlı Askeri Kurumlarında Boğazların Haritalanması: İstanbul Üniversitesi Koleksiyonları Üzerinden Toplu Bir Bakış / La Cartographie des Détroits dans les Institutions militaires ottomanes au XIXe siècle." $\ddot{U}_{c}$ Denizin Arasında- Osmanlı ve Fransız Boğaz Haritaları / Entre Trois Mers-Cartographie ottomane et française des Dardanelles et du Bosphore. Editörler: Jean François Pérouse ve Feza Günergun, 144-173. İzmir: Arkas Sanat Merkezi, 2016.

Üçsu, Kaan ve Feza Günergun. "Harita Tersimi Atlası Işığında Osmanlı Askeri Okul Öğrencilerinin Harita Derslerine Tanıklık / Témoignage sur les Cours de Cartographie dispensés dans les Écoles militaires ottomanes au Regard du Manuel Harita Tersimi Atlast." $\ddot{U} c ̧$ Denizin Arasında- Osmanlı ve Fransız Boğaz Haritaları / Entre Trois Mers-Cartographie ottomane et française des Dardanelles et du Bosphore. Editörler: Jean François Pérouse ve Feza Günergun, 204-11. İzmir: Arkas Sanat Merkezi, 2016.

Üçsu, Kaan. "İstanbul Üniversitesi Nadir Eserler Kütüphanesi," Üç Denizin ArasındaOsmanlı ve Fransız Boğaz Haritalarl, Üç Denizin Arasında- Osmanlı ve Fransız Boğaz Haritaları / Entre Trois Mers-Cartographie ottomane et française des Dardanelles et du Bosphore. Editörler: Jean François Pérouse ve Feza Günergun, 214-215. İzmir: Arkas Sanat Merkezi, 2016.

33 https://avesis.istanbul.edu.tr/kaan.ucsu. Erişim 4 Nisan 2021. 
Üçsu, Kaan. "The Small Plane Table an Invention by an Ottoman Military Officer." XXXVth Scientific Instrument Symposium - Instruments between East and West - Abstracts, 23. İstanbul, 2016.

Üçsu, Kaan. "Witnesses of the Time: A Survey of Clock Rooms, Clock Towers and Façade Clocks in Istanbul in the Ottoman Era.” Rubrica Contemporanea 6, 12 (2017): 43-60.

Üçsu, Kaan. "Cartographies of the 'Eastern Question': Some Considerations on Mapping the Sea of Marmara and the Black Sea in the Nineteenth Century." Philosophy of Globolization. Editörler: Roldan Concha, Brauer Daniel, Rohbeck Johannes, 253-269. Berlin: Walter de Gruyter, Inc., 2018.

Üçsu, Kaan. “İbrahim Müteferrika’nın Haritacılık Çalışmalarına Bir Bakış.” Sahn-ı Semân'dan Darülfünûn'a Osmanlı'da İlim ve Fikir Dünyası: Âlimler Müesseseler ve Fikrî Eserler XVIII. Yüzyıl, Editörler: Ahmet Hamdi Furat, Nilüfer Yorulmaz Kalkan, Osman Sacid Ar1, 201-233. İstanbul: Zeytinburnu Belediyesi Kültür Yayınları, 2019.

Üçsu, Kaan. "Bahriyye-i Bahri Siyah, 1724-5, of the Black Sea Ibrahim Muteferrika's Map and its copies in Bibliothèque Nationale de France." IMCOS Journal 156 (2019): 29-40.

Üçsu, Kaan. "Tarek Kahlaoui, Creating the Mediterranean: Maps and the Islamic Imagination." Nazariyat 6, 1 (2020): 246-249.

Üçsu, Kaan. "Zayde Antrim, Mapping the Middle East, London: Reaktion Books, 2018, 333 pp., 82 illustrations, ISBN 9781780238500.” Der Islam 97, 2 (2020): 570-572 (yayın tanitimi).

\section{Bildiriler (özeti yayınlanmamış)}

Üçsu, Kaan. "Mapping the Sea of Marmara and the Black Sea: Circulation of the Cartographical Knowledge Between Europe and the Ottoman Empire in 19th" Century." Global Traffic: Production and Circulation of Knowledge and Ideas across the Borders atölye çalışmasında (Madrid, Haziran 2016) sunulan bildiri.

Üçsu, Kaan. "Two Maps of Asia Minor: A Comparison of Joan Blaeu’s and Abu Bakr b. Bahram Al Dimashqî's Works.” The 25th International Congress on the History of Science'da (Rio de Janeiro, 23-29 Temmuz 2017) sunulan bildiri.

Üçsu, Kaan. "Ibrahim Müteferrika's map of Black Sea and its copies in Bibliothèque National de France." The 27th International Conference on the History of Cartography'de (Belo Horizonte, Brezilya, 9-14 Temmuz 2017) sunulan bildiri. 
Üçsu, Kaan. “İbrahim Müteferrika’nın Haritacılık Çalışmalarına Bir Bakış.” Sahn-1 Semân'dan Darülfünûn'a Osmanlı'da İlim ve Fikir Dünyası Toplantısında (İstanbul, 23-25 Aralık 2017) sunulan bildiri.

Üçsu, Kaan. “Abu Bakr b. Bahram Al Dimashqî̀s (d.1691) Account on the Discovery of the New World in his Translation of Atlas Maior." Shared Practices Common Legacies'de (Philadelphia, ABD, 5-8 Nisan 2019) sunulan bildiri.

Üçsu, Kaan. "Fuat Sezgin İslam Matematiksel Coğrafyacılığı Hakkındaki Görüşleri." Fuat Sezgin'nin Eserlerini Okuma Seminerleri kapsamında İstanbul Üniversitesi Avrasya Araştırmaları Enstitüsünde sunulan bildiri, İstanbul, 27 Nisan 2019.

Üçsu, Kaan. "Spain in the Geography of Abu Bakr b. Bahram al-Dimashqi." Science and Technology in al-Andalus and in the Ottoman Empire, in Memoriam Prof. Fuat Sezgin başlıklı toplantıda (Madrid, 28 Haziran 2019) sunulan bildiri.

Üçsu, Kaan. “Translation of Atlas Maior into Turkish.” Young Scholars Conference of the European Society for the History of Science (ESHS) başlıklı toplantıda (Paris, 10-12 Eylül 2019) sunulan bildiri.

Üçsu, Kaan. “Ajaib in Abu Bakr al-Dimashqî’s Geography.” Nature and the Supernatural in Ottoman Culture başlıklı toplantıda (İstanbul, Columbia Global Centers, 14-15 Aralık 2019) sunulan bildiri.

\section{Bilimsel Araştırma Projeleri}

Üçsu, Kaan (yardımcı araştırmacı). "Çanakkale ve İstanbul Boğazları Haritalarının (1719.yy) Haritacılık ve Bilim Tarihi Açısından İncelenmesi” konulu BAP projesi (Normal proje, Proje No: 44531) Başlangıç ve bitiş tarihi: 25.7.2014-12.12.2016, Proje yürütücüsü: Feza Günergun) (İngiltere'de British Library'de (Londra) 06-15 May1s 2016 tarihleri arasında yürütülen bilimsel araştırma).

Üçsu, Kaan (araştırmacı). Philosophy of History and Globalisation of Knowledge. Cultural Bridges Between Europe and Latin America (WORLDBRIDGES), Avrupa Birliği 7. Çerçeve Programı, FB7-PEOPLE-2013-IRSES. GA: 612644) Projesi, 1 Mart 2014-28 Şubat 2018.

\section{Diğer etkinlikler}

Üçsu, Kaan (ziyaretçi araştırmacı). University of Michigan, USA, TÜBİTAK 2214-A bursu ile Prof. Dr. Gottfried Hagen danışmanlığında 8 ay bilimsel araştırma, Başlangıç ve bitiş tarihi: Ekim 2017-Haziran 2018. 
Hakem Değerlendirmesi: Dış bağımsız.

Çıkar Çatışması: Yazar çıkar çatışması bildirmemiştir.

Finansal Destek: Yazar bu çalışma için finansal destek almadığını beyan etmiştir.

Peer-review: Externally peer-reviewed.

Conflict of Interest: The author has no conflict of interest to declare.

Grant Support: The author declared that this study has received no financial support.

\section{KAYNAKÇA / BIBLIOGRAPHY}

\section{Basılı Kaynaklar / Printed Sources}

Bir, Atilla. "Bilimsel aletlerin Doğu ile Batı arasındaki yolculuğu." Osmanlı Bilimi Araştırmaları 21, 2 (2020): 423-426.

Brown, Neil. "XXXVth Scientific Instrument Symposium.” Osmanlı Bilimi Araştırmaları 18, 2 (2017): 104115.

Brown, Neil, Silke Ackermann ve Feza Günergun (editörler). Scientific Instruments between East and West. Leiden-Boston: Brill, 2019.

Çetinkaya, Nur Banu. "Bilginin İzinde: İstanbul Üniversitesi Koleksiyonlarından Bilimsel Aletler, Yazmalar, Baskılar (İstanbul, 26 Eylül-26 Aralık 2016).” Osmanlı Bilimi Araştırmaları 18, 2 (2017): 116-118.

Esatoğlu, Elif Çınar. "İstanbul Üniversitesi Bilim Tarihi Bölümünde Konferans: Periyodik Çizelgenin 150 Yıllık Öyküsü.” Osmanlı Bilimi Araştırmaları 21, 1 (2020): 219-223.

Günergun, Feza (editör). Pursuing Knowledge, Scientific Instruments, Manuscripts and Prints from Istanbul University Collections/Bilginin İinde-İstanbul Üniversitesi Koleksiyonlarindan Bilimsel Aletler, Yazmalar, Baskilar. İstanbul, 2016.

Günergun, Feza (Bilim Tarihi Bölümü adına). "İstanbul Üniversitesi Edebiyat Fakültesi Bilim Tarihi Bölümü 2018-2019 Seminer, Konferans, Ziyaret ve Buluşmaları.” Osmanlı Bilimi Araştırmaları 20, 2 (2019): 171-179.

Özdemir, Solmaz Ceren. "II. İstanbul Üniversitesi Edebiyat Fakültesi Bilim Tarihi Bölümü Öğrenci Kongresi." Osmanlı Bilimi Araştırmaları 18, 1 (2016): 98-99.

Özdemir, Solmaz Ceren. "İstanbul Üniversitesi Edebiyat Fakültesi Bilim Tarihi Bölümü III. Öğrenci Kongresi.” Osmanlı Bilimi Araştırmaları 18, 2 (2017): 118-121.

[Polat] Danışan, Gaye. "35. Uluslararası Bilim Aletleri Sempozyumu: Doğu ile Batı Arasında Bilim Aletleri (İstanbul, 26-30 Eylül 2016).” Osmanlı Bilimi Araştırmaları 18, 2 (2017): 93-97.

Sanıyar, Ahmet, Burcu Buyurman ve Elif Çınar Esatoğlu. "İstanbul Üniversitesi Edebiyat Fakültesi Bilim Tarihi Bölümü V. Öğrenci Kongresi.” Osmanlı Bilimi Araştırmaları 20, 2 (2019): 181-184.

Shea, William R. "Feza Günergun (ed.), Pursuing Knowledge. Istanbul, 2016, pp.149." Archives Internationales d'Histoire des Sciences 66, 176 (2016): 28-50. 


\section{Elektronik kaynaklar / Electronic sources}

https://avesis.istanbul.edu.tr/atilla.polat. Erişim 4 Nisan 2021.

https://avesis.istanbul.edu.tr/bariscan.ersoz. Erişim 4 Nisan 2021.

https://avesis.istanbul.edu.tr/danpolat. Erişim 4 Nisan 2021.

https://avesis.istanbul.edu.tr/gayesah. Erişim 4 Nisan 2021.

https://avesis.istanbul.edu.tr/gunerfez. Erişim 4 Nisan 2021.

https://avesis.istanbul.edu.tr/kaanata. Erişim 4 Nisan 2021.

https://avesis.istanbul.edu.tr/kaan.ucsu. Erişim 4 Nisan 2021.

https://avesis.istanbul.edu.tr/makbas. Erişim 4 Nisan 2021.

https://avesis.istanbul.edu.tr/sevtapk. Erişim 4 Nisan 2021.

Yükseköğretim Kanunu ile Bazı Kanun ve Kanun Hükmünde Kararnamelerde Değişiklik Yapılması Hakkında

Kanun. Erişim: 08.12.2020. https://www.resmigazete.gov.tr/eskiler/2018/03/20180306-11.htm. 
